\title{
Modeling the aging process of black carbon during atmospheric transport using a new approach: a case study in Beijing
}

\author{
Yuxuan Zhang ${ }^{1,2}$, Meng Li ${ }^{2}$, Yafang Cheng ${ }^{2}$, Guannan Geng ${ }^{3}$, Chaopeng Hong ${ }^{4}$, Haiyan $\mathrm{Li}^{1}, \mathrm{Xin} \mathrm{Li}^{5}$, Dan Tong ${ }^{4}$, \\ Nana $\mathrm{Wu}^{1}$, Xin Zhang ${ }^{1}$, Bo Zheng ${ }^{6}$, Yixuan Zheng ${ }^{7}$, Yu Bo ${ }^{1,8}$, Hang Su ${ }^{2}$, and Qiang Zhang ${ }^{1}$ \\ ${ }^{1}$ Department of Earth System Science, Tsinghua University, Beijing 100084, China \\ ${ }^{2}$ Multiphase Chemistry Department, Max Planck Institute for Chemistry, 55128 Mainz, Germany \\ ${ }^{3}$ Department of Environmental Health, Rollins School of Public Health, Emory University, Atlanta, GA 30322, USA \\ ${ }^{4}$ Department of Earth System Science, University of California, Irvine, CA 92697, USA \\ ${ }^{5}$ Department of Environmental Science and Engineering, Beijing Technology and Business University, Beijing 100048, China \\ ${ }^{6}$ Laboratoire des Sciences du Climate et de l'Environnement LSCE, Batiment 706, Pte 25, Orme de Merisiers, \\ 91191 Gif-sur-Yvette, France \\ ${ }^{7}$ Department of Global Ecology, Carnegie Institution for Science, CA 94305, USA \\ ${ }^{8}$ RCE-TEA, Institute of Atmospheric Physics, Chinese Academy of Science, Beijing 100029, China
}

Correspondence: Qiang Zhang (qiangzhang@tsinghua.edu.cn) and Yu Bo (boyu@mail.iap.ac.cn)

Received: 1 February 2019 - Discussion started: 1 April 2019

Revised: 24 June 2019 - Accepted: 6 July 2019 - Published: 31 July 2019

\begin{abstract}
The effect of black carbon (BC) on air quality and the climate is still unclear, which is partly because of the poor understanding regarding the $\mathrm{BC}$ aging process in the atmosphere. In this work, we developed a new approach to simulate the $\mathrm{BC}$ mixing state (i.e., other species coated on the $\mathrm{BC}$ surface) based on an emissions inventory and back-trajectory analysis. The model tracks the evolution of the BC aging degree (characterized by the size ratio of the whole particle and $\mathrm{BC}$ core) during atmospheric transport. Using the models, we quantified the mass-averaged aging degree of total $\mathrm{BC}$ particles transported to a receptor (e.g., an observation site) from various emission origins (i.e., $0.25^{\circ} \times 0.25^{\circ}$ grids). The simulations showed good agreement with the field measurements, which validated our model calculation. Modeling the aging process of $\mathrm{BC}$ during atmospheric transport showed that it was strongly dependent on emission levels. BC particles from extensive emission origins (i.e., polluted regions) were characterized by a higher aging degree during atmospheric transport due to more co-emitted coating precursors. On the other hand, high-emission regions also controlled the aging process of $\mathrm{BC}$ particles that were emitted from cleaner regions and passed through these polluted regions during atmospheric transport. The simulations identified the important roles of extensive emission regions in the $\mathrm{BC}$ aging process
\end{abstract}

during atmospheric transport, implying the enhanced contributions of extensive emission regions to BC light absorption. This provides a new perspective on the phenomenon of pollution building up in the North China Plain, further demonstrating that this is mainly driven by regional transport and transformation. The simulation of the $\mathrm{BC}$ aging degree during atmospheric transport provided more clues for improving air pollution and climate change.

\section{Introduction}

Black carbon (BC) plays an important role in the global warming and deterioration of air quality (Bond et al., 2013). The effects of BC aerosols on air quality and climate strongly depend on their light absorption. Accurately assessing the radiative effects of $\mathrm{BC}$ aerosols continues to be a major challenge in atmospheric/climate sciences, partly due to unclear light absorption capability of ambient BC particles. Estimates of the light absorption enhancement for BC-containing aerosols caused by coating materials on BC surface differ by a factor of $\sim 3.5$, spanning over a wide range from 1.05 to 3.5 (Cappa et al., 2012; Jacobson, 2001; Moffet et al., 2009; Peng et al., 2016). Generally, the aged BC particles during 
atmospheric transport exhibit a stronger absorption capability compared to near-source BC aerosols (Dahlkötter et al., 2014; Gustafsson and Ramanathan, 2016). In some climate model studies, the light absorption properties obtained from near-source $\mathrm{BC}$ aerosols are taken to estimate the direction radiative forcing (DRF) of BC (X. Wang et al., 2014; Schulz et al., 2006; Myhre et al., 2009). However, the climate effects of $\mathrm{BC}$ aerosols are on the regional to even global scales. Meanwhile, the effect of $\mathrm{BC}$ on air quality by the suppression on the planetary boundary layer (PBL) is associated with the atmospheric aging process of BC particles (Ding et al., 2016; Z. Wang et al., 2018). Therefore, better understanding light absorption properties during atmospheric transport can improve the model prediction of $\mathrm{BC}$ effects on climate and air quality.

The change in light absorption of BC-containing particles during atmospheric transport is associated with the evolution of their mixing state. During atmospheric transport from emission sources, BC can internally mix with other atmospheric species (e.g., sulfate, nitrate, secondary organic matter and named coating materials) by condensation and coagulation processes (Jacobson, 2001; Li et al., 2016; Liu et al., 2017; Moffet et al., 2009). The interaction between $\mathrm{BC}$ and other aerosol components is defined as the BC aging process. Jacobson (2001), Cheng et al. (2006), Lack and Cappa (2010), Liu et al. (2015) and Zhang et al. (2016) pointed out that aged BC can exhibit light absorption amplification by 2-3 times due to the lensing effect of the coating material on the $\mathrm{BC}$ surface, which influences the DRF of BC and then also impacts the development of the PBL (Cheng et al., 2008, 2009; Chung et al., 2012; Moffet et al., 2009; Ramanathan and Carmichael, 2008; Wendisch et al., 2008; Nordmann et al., 2014; Ding et al., 2016). However, the light absorption capability of $\mathrm{BC}$ during the aging process is still under debate (Cappa et al., 2012; Jacobson, 2001; Liu et al., 2017) partly due to a lack of understanding of the $B C$ mixing state during atmospheric transport.

The mixing state of atmospheric BC-containing particles can be quantified by field observations, aircraft measurements and model simulations. Field measurements obtain the mixing state of $\mathrm{BC}$ particles as they are transported to an observation site (Cheng et al., 2006, 2012; Moffet et al., 2009; Sedlacek et al., 2012; Zhang et al., 2018a, c). These observations characterize the average mixing state of $\mathrm{BC}$ over the observation site and cannot distinguish the mixing state of BC particles from different source origins. Moreover, field observations cannot be used to understand the temporal and spatial variations in the $\mathrm{BC}$ mixing state during atmospheric transport. Aircraft measurements are commonly applied to explore the evolution of the $\mathrm{BC}$ mixing state during atmospheric transport from emission sources (Dahlkötter et al., 2014; Ditas et al., 2018; McMeeking et al., 2011; Moteki et al., 2007). However, aircraft measurements are currently limited due to high costs, especially in developing countries with high $\mathrm{BC}$ emissions (e.g., China and India). On the other hand, some models have been developed to simulate the mixing state of BC-containing aerosols based on the mass or volume concentrations of BC and non-BC components (Jacobson, 2001; Matsui et al., 2013; Oshima et al., 2009). The major challenge of these models is how to treat non-BC components as coating materials of $\mathrm{BC}$ and $\mathrm{BC}$-free particles. Moreover, when using these models, the computational cost is high when simulating the $\mathrm{BC}$ mixing state during atmospheric transport (Matsui et al., 2013). A lack of information on the $\mathrm{BC}$ mixing state during the transport process will prevent a good understanding of the light absorption of $\mathrm{BC}$ particles in the atmosphere.

Considering the important contribution of $\mathrm{BC}$ from polluted regions to the $\mathrm{BC}$ amount present in the regional atmosphere (Lu et al., 2012; Zhang et al., 2018c), studies on $\mathrm{BC}$ aging during atmospheric transport should pay more attention to $\mathrm{BC}$ particles from polluted regions. Based on in situ measurements, Zhang et al. (2018c) found that the light absorption capability of BC increased with increasing levels of air pollution due to more coating materials of $\mathrm{BC}$ under more polluted conditions. Cheng et al. (2012) showed that the aging process in polluted areas, such as Beijing, was much faster than that in clean or less polluted regions (Moteki et al., 2007; Shiraiwa et al., 2007) and in modeling studies (Cooke and Wilson, 1996; Jacobson, 2001; Koch, 2001; Lohmann et al., 2000). Peng et al. (2016) also pointed out a higher aging rate of $\mathrm{BC}$ particles under more polluted environments. Moreover, Li et al. (2016) and Wang et al. (2017) revealed that the significant change in BC morphology (e.g., increase in fraction dimension) associated with their mixing state (i.e., from bare-like or partly coated to embedded BC) in polluted air, which could enhance BC light absorption (Liu et al., 2015; Peng et al., 2016). These studies identified the importance of understanding the mixing state of $\mathrm{BC}$ during atmospheric transport from polluted regions.

In this work, we developed a new approach to simulate the evolution of the $\mathrm{BC}$ mixing state during atmospheric transport based on BC emission inventory and back-trajectory analyses. First, the model calculation was used to simulate the mass-weighted mixing state of overall $\mathrm{BC}$ particles at a Beijing site with a fine temporal resolution of $1 \mathrm{~h}$, which was compared with the in situ measurements to evaluate our models. We then used our model to separate the mixing state of BC-containing particles from various spatial origins $\left(0.25^{\circ} \times 0.25^{\circ}\right.$ resolution $)$ as they were transported to a receptor site in Beijing during a pollution period in late autumn. Based on the simulations, we focused on the mixing state of $\mathrm{BC}$ from polluted regions and discussed the dependence of the $\mathrm{BC}$ mixing state during atmospheric transport on emission levels. Finally, we explored the implication for the BC light absorption during atmospheric transport, especially for $\mathrm{BC}$ from polluted regions. 
Table 1. The in situ measurement in this work. $\left(D_{\mathrm{p}} / D_{\mathrm{c}}\right)_{5} \%$ represents the average value of the lowest 5 th percentile of the hourly $D_{\mathrm{p}} / D_{\mathrm{c}}$ ratio for ambient $\mathrm{BC}$-containing particles during the campaign period.

\begin{tabular}{lllrrrr}
\hline \multirow{2}{*}{ Measurement } & Period & Location & $\begin{array}{r}\text { Hourly } \mathrm{PM}_{2.5} \\
\left(\mu \mathrm{g} \mathrm{m}^{-3}\right)\end{array}$ & $\begin{array}{r}\text { Hourly rBC } \\
\left(\mu \mathrm{g} \mathrm{m}^{-3}\right)\end{array}$ & $\begin{array}{r}\text { Hourly } \\
D_{\mathrm{p}} / D_{\mathrm{c}}\end{array}$ & $\left(D_{\mathrm{p}} / D_{\mathrm{c}}\right)_{5 \%}$ \\
\hline BJNOV2014 & 17-30 November 2014 & Tsinghua site, Beijing & $\sim 10-440$ & $\sim 0.2-14$ & $\sim 1.4-2.3$ & 1.54 \\
BJOCT2014 & 28 October-2 November 2014 & Tsinghua site, Beijing & $\sim 5-200$ & $\sim 0.1-7$ & $\sim 1.4-2.2$ & 1.50 \\
BJSEP2015 & 12-19 September 2015 & Tsinghua site, Beijing & $\sim 3-190$ & $\sim 0.1-4$ & $\sim 1.5-2.2$ & 1.55 \\
BJAUG2015 & 16-23 August 2015 & Tsinghua site, Beijing & $\sim 3-110$ & $\sim 0.1-3$ & $\sim 1.5-2.0$ & 1.55 \\
\hline
\end{tabular}

\section{Data and methods}

\subsection{Data}

\subsubsection{Measured aging degree of $\mathrm{BC}$}

In this study, the aging degree of $\mathrm{BC}$ particles was characterized by the $D_{\mathrm{p}} / D_{\mathrm{c}}$ ratio (i.e., the size ratio of the whole particle (including coatings and $\mathrm{BC}$ core) and the $\mathrm{BC}$ core). The observed $D_{\mathrm{p}} / D_{\mathrm{c}}$ ratio of $\mathrm{BC}$-containing particles is measured using a single-particle soot photometer (SP2) in this work. The SP2 technique (Droplet Measurement Technology, Boulder, CO, USA) has been described in detail elsewhere (Sedlacek et al., 2012; Moteki and Kondo, 2010; Zhang et al., 2016, 2018b). In brief, SP2 uses incandescence and scattering signals induced by a Nd:YAG intracavity laser beam at $1064 \mathrm{~nm}$ to quantify the refractory $\mathrm{BC}(\mathrm{rBC})$ mass and the scattering cross section of individual $\mathrm{BC}$-containing particles. The $\mathrm{rBC}$ mass determined from incandescence signals of SP2 was calibrated with Aquadag particles of known masses. Details on SP2 calibration were shown in previous studies (Zhang et al., 2018c). To retrieve the scattering cross section of BC-containing particles from scattering signals of SP2, a leading edge only (LEO) fit method was used (Gao et al., 2007). The whole particle diameter $\left(D_{\mathrm{p}}\right)$ and the BC core diameter $\left(D_{\mathrm{c}}\right)$ were derived from the SP2 measurement and Mie theory, as given by Zhang et al. (2016, 2018c). In Mie calculation, the refractive indices of the $\mathrm{rBC}$ core and coating materials were prescribed the values of 2.26-1.26i (Taylor et al., 2015; Zhang et al., 2018b) and 1.50-0i (Cappa et al., 2012; Zhang et al., 2018c); the density of the rBC core was used as the value of $1.8 \mathrm{~g} \mathrm{~cm}^{-3}$ (Cappa et al., 2012; Taylor et al., 2015). The hourly mass-average $D_{\mathrm{p}} / D_{\mathrm{c}}$ ratio of $\mathrm{BC}$-containing particles is used in this work.

Table 1 lists the field observations: BJNOV2014 (performed on 17-30 November 2014, Fig. 1), BJOCT2014 (performed from 28 October to 2 November 2014), BJSEP2015 (performed on 12-19 September 2015) and BJAUG2015 (performed on 17-23 August 2015). The observation site $\left(40^{\circ} 00^{\prime} 17^{\prime \prime} \mathrm{N}, 116^{\circ} 19^{\prime} 34^{\prime \prime} \mathrm{E}\right.$, shown in Fig. 2a) is located at Tsinghua University in the downtown area of Beijing and can be representative of the urban environment (Zhang et al., 2018a, c). In this study, the Tsinghua site was taken as the receptor of $\mathrm{BC}$ particles from emission origins (e.g., Hebei,

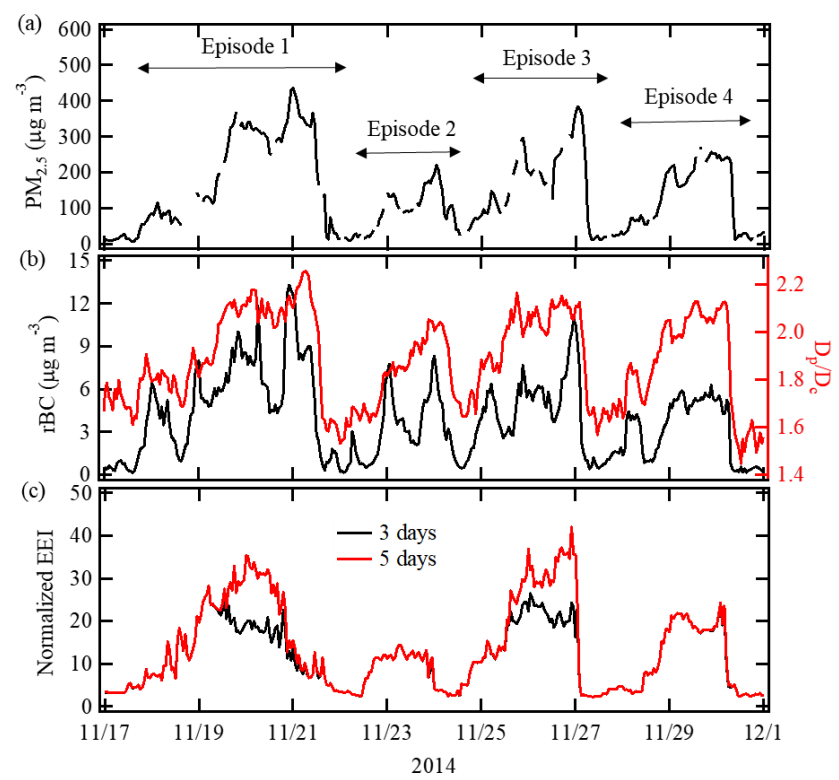

Figure 1. Time series of the $\mathrm{PM}_{2.5}$ concentration, $\mathrm{rBC}$ mass concentration, $D_{\mathrm{p}} / D_{\mathrm{c}}$ ratio of BC-containing particles and the hourly EEI for BC transported to the observation site for 3-day and 5-day back-trajectories during the BJNOV2014 period.

Tianjin, Shandong, Shanxi, Shaanxi and Inner Mongolia, Fig. 2a) during atmospheric transport. The BJNOV2014 measurement contained several pollution episodes (Fig. 1a), which featured the evolution of $\mathrm{BC}$ aging degree (i.e., $D_{\mathrm{p}} / D_{\mathrm{c}}$ ratio) associated with air pollution in the range of 1.4-2.3 (Fig. 1b). During the BJNOV2014 campaign period, BC amount transported to the Tsinghua site was dominated by the emission of Beijing and its surrounding areas (i.e., Hebei, Tianjin, Shanxi, Shaanxi and Inner Mongolia) (Fig. 3). Moreover, Fig. 3 shows that the spatial origins of $\mathrm{BC}$ over the observation site during the four pollution episodes for the BJNOV2014 measurement were different (e.g., urban, rural and industrial sources) based on back-trajectory analysis ( $\mathrm{Lu}$ et al., 2012). Thereby, the $\mathrm{BC}$ aging degree (i.e., $D_{\mathrm{p}} / D_{\mathrm{c}}$ ratio) obtained from BJNOV2014 measurement was representative and was used to establish the model in this study. The other measurement periods (i.e., the BJOCT2014, BJSEP2015 and BJAUG2015 cases) were characterized by 


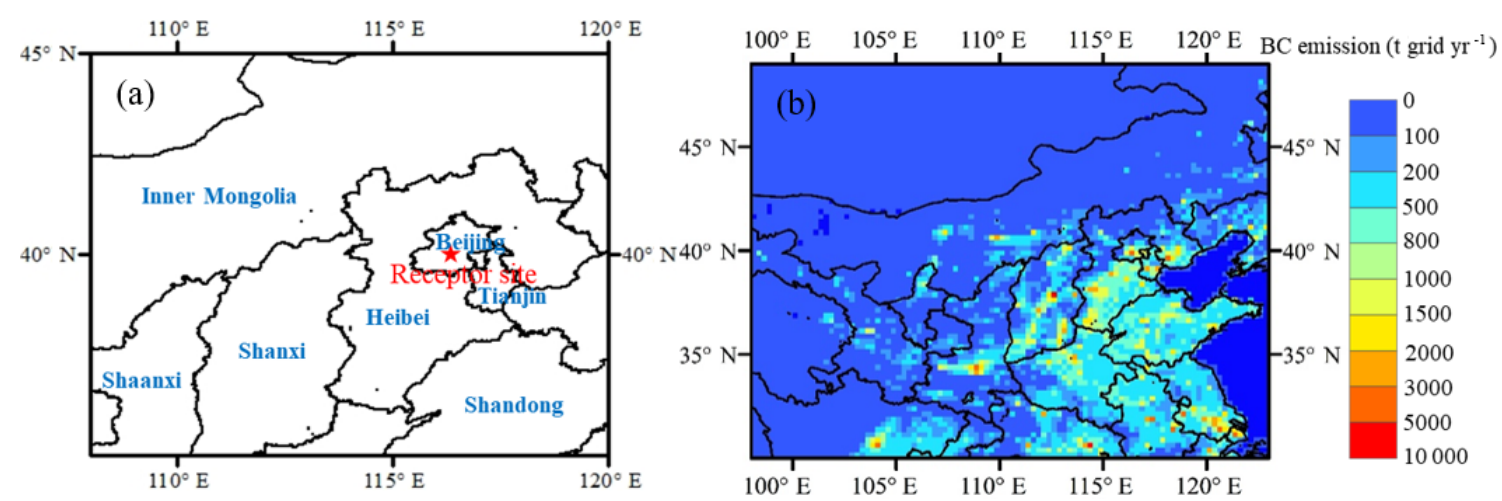

Figure 2. (a) The location of the receptor site (Tsinghua site $\left(40^{\circ} 00^{\prime} 17^{\prime \prime} \mathrm{N}, 116^{\circ} 19^{\prime} 34^{\prime \prime} \mathrm{E}\right)$, marked as a red star) during the BJNOV2014 measurement period. (b) Spatial distribution $\left(0.25^{\circ} \times 0.25^{\circ}\right)$ of the BC emission inventory from MIX.

the evolution of pollution episodes (i.e., from clean hours to slight pollution and then reaching to the pollution period and finally retuning to clean hours), which were used to identify whether the models could simulate $\mathrm{BC}$ aging degree with a high time resolution (i.e., $1 \mathrm{~h}$ ) to characterize the change in $\mathrm{BC}$ mixing state associated with air pollution.

\subsubsection{Back-trajectory analysis and BC emissions}

During atmospheric transport, information on the location, height and transport time of BC-containing particles is obtained from back-trajectory analysis using the Hybrid Single-Particle Lagrangian Integrated Trajectory (HYSPLIT) model, with the meteorological fields from the National Centers for Environmental Prediction (NCEP) Global Data Assimilation System (GDAS). Back-trajectories with an hourly temporal resolution were calculated. The arrival height was set as $100 \mathrm{~m}$. We ran the trajectories backwards for 3, 5 and 7 days. The effective amount of BC transported to the observation site derived from the 5-day back-trajectories was similar to that from the 7-day back-trajectories, which was significantly larger than that from the 3-day backtrajectories (Fig. 1c). The 5-day back-trajectories were used in the following model calculation.

The gridded BC emissions for the years 2014 and 2015 were obtained from the MIX inventory, with a resolution of $0.25^{\circ} \times 0.25^{\circ}$ (http://www.meicmodel.org/dataset-mix, last access: 18 October 2018). The MIX inventory includes the emission data of anthropogenic sources in Asia ( $\mathrm{Li}$ et al., 2017). Figure $2 b$ shows the gridded $B C$ emissions at $0.25^{\circ} \times$ $0.25^{\circ}$ in Beijing and its surrounding regions (i.e., Hebei, Tianjin, Shandong, Shanxi, Shaanxi and Inner Mongolia).

\subsection{Model development of $\mathrm{BC}$ aging during atmospheric transport}

The BC aging process during atmospheric transport depends on the formation of coating materials (i.e., other species (e.g., sulfate, nitrate and organics) on the $\mathrm{BC}$ surface by condensa- tion and coagulation). The more coating materials there are on the $\mathrm{BC}$ surface, the more aged $\mathrm{BC}$ during atmospheric transport. The quantity of coating materials during atmospheric transport strongly depends on the pollutant emission levels and $\mathrm{BC}$ transport time. In this study, the rate of change in coating mass ( $\left.m_{\text {coating }}\right)$ on $\mathrm{BC}$ is defined as

$\frac{\mathrm{d} m_{\text {coating }}}{\mathrm{d} t}=k_{\text {aging }} E$,

where $t$ represents the transport time; $k_{\text {aging }}$ represents the aging rate coefficient; and $E$ represents the emissions level of coating precursors, which are co-emitted with BC. To simplify the calculation, $E$ is quantified by $\mathrm{BC}$ emissions from the MIX inventory. The variable $m_{\text {coating }}$ is calculated by Eq. (2):

$m_{\text {coating }}=\frac{1}{6} \pi D_{\mathrm{p}}^{3} \rho_{\mathrm{p}}-\frac{1}{6} \pi D_{\mathrm{c}}^{3} \rho_{\mathrm{c}}$,

where $\rho_{\mathrm{p}}$ and $\rho_{\mathrm{c}}$ represent the densities of the whole BCcontaining particles (including coating materials and $\mathrm{BC}$ core) and the $\mathrm{BC}$ cores only, respectively.

Combining Eqs. (1) and (2), the BC mixing state (i.e., the $D_{\mathrm{p}} / D_{\mathrm{c}}$ ratio) during atmospheric transport can be calculated as

$\left(\frac{D_{\mathrm{p}}}{D_{\mathrm{c}}}\right)^{3}=k E_{\mathrm{aver}} t+\left(\frac{D_{\mathrm{p}}}{D_{\mathrm{c}}}\right)_{t=0}^{3}$,

where $E_{\text {aver }}$ is the average $\mathrm{BC}$ emissions during transport and $k$ represents the normalized aging rate coefficient, which is expressed as

$k=\frac{6 k_{\mathrm{aging}}}{\rho_{\mathrm{p}} \pi D_{\mathrm{c}}^{3}}$.

Following Eq. (3), we calculated the $D_{\mathrm{p}} / D_{\mathrm{c}}$ ratio of $\mathrm{BC}$ aerosols transported to the receptor site from different source origins with a $0.25^{\circ} \times 0.25^{\circ}$ resolution (i.e., the originresolved mixing state of $\mathrm{BC}$ ). The conceptual scheme of 


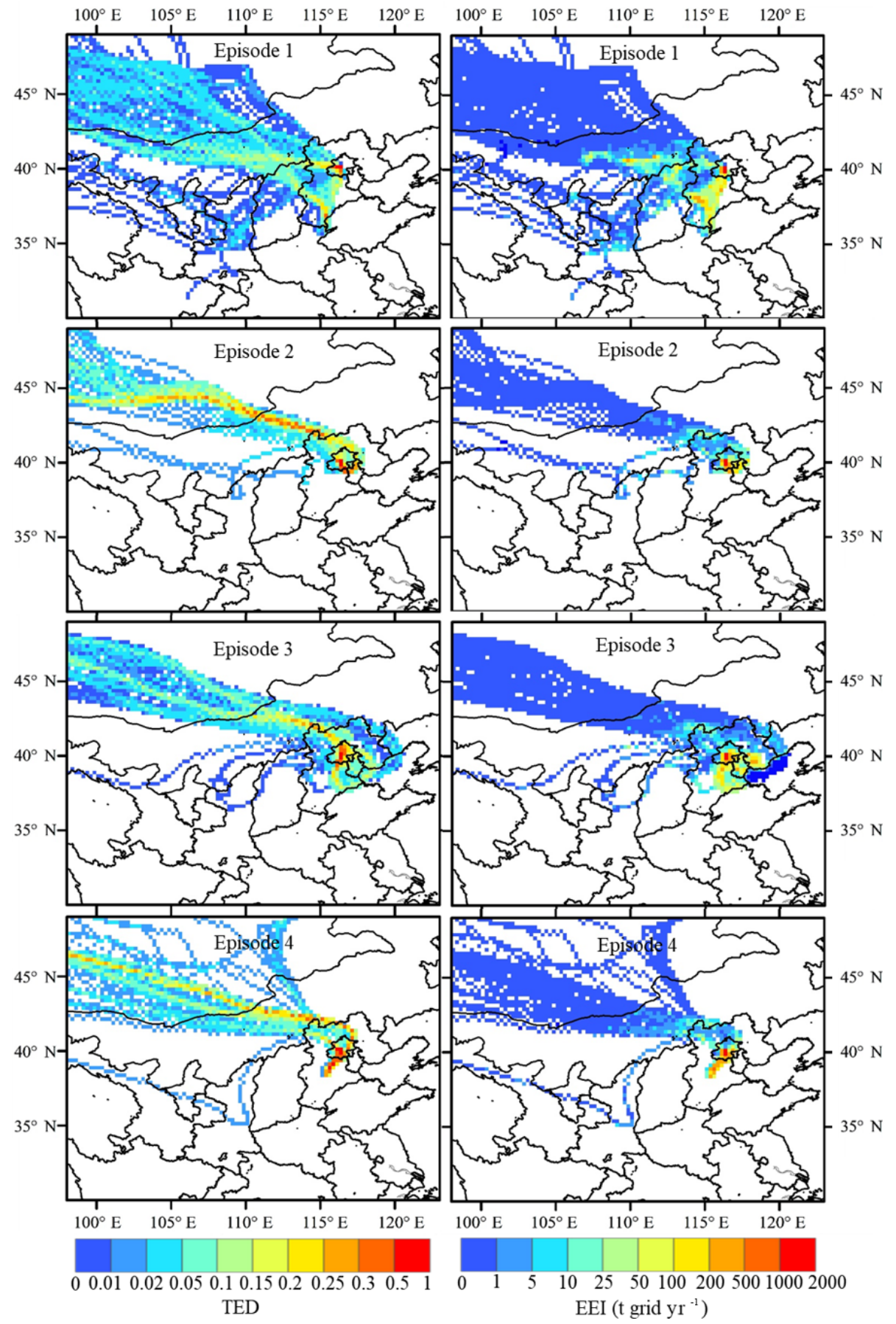

Figure 3. Spatial distribution $\left(0.25^{\circ} \times 0.25^{\circ}\right)$ of the TED and EEI for BC transported to the observation site $\left(40^{\circ} 00^{\prime} 17^{\prime \prime} \mathrm{N}, 116^{\circ} 19^{\prime} 34^{\prime \prime} \mathrm{E}\right)$ during episodes 1-4 of the BJNOV2014 measurement period. The TED and EEI were derived from BC emission and black-trajectory analysis (Lu et al., 2012). The TED represents effective trajectory density transported to the receptor site. The EEI quantifies the effective emission amount transported to the receptor site from emission origins. 


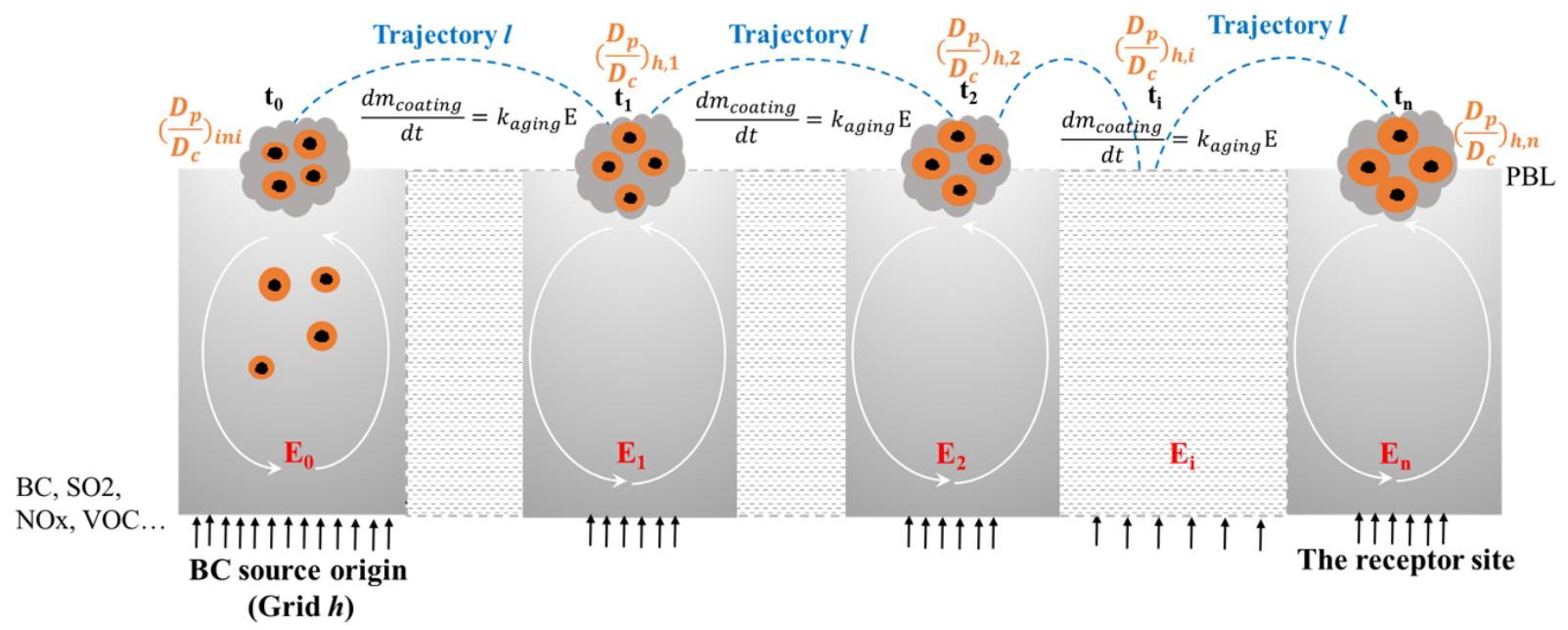

Figure 4. Conceptual scheme of the evolution of the mixing state (i.e., the $D_{\mathrm{p}} / D_{\mathrm{c}}$ ratio) of $\mathrm{BC}$ from the source origin (i.e., grid $h$ ) to the receptor site following trajectory $l$.

the evolution of the $\mathrm{BC}$ mixing state (i.e., the $D_{\mathrm{p}} / D_{\mathrm{c}}$ ratio) during atmospheric transport is shown in Fig. 4. When BC aerosols emitted in a grid, $h$, were transported to the receptor site following a trajectory, $l$ (Fig. 4$)$, the $D_{\mathrm{p}} / D_{\mathrm{c}}$ ratio (i.e., $\left.\left(\frac{D_{\mathrm{p}}}{D_{\mathrm{c}}}\right)_{h, l}\right)$ is given, as shown in Eq. (5):

$\left(\frac{D_{\mathrm{p}}}{D_{\mathrm{c}}}\right)_{h, l}^{3}=k E_{\mathrm{aver}, h, l} t_{h, l}+\left(\frac{D_{\mathrm{p}}}{D_{\mathrm{c}}}\right)_{\mathrm{ini}}^{3}$,

where $E_{\mathrm{aver}, h, l}$ and $t_{h, l}$ represent the average BC emissions (unit of $\mathrm{tgrid}^{-1} \mathrm{yr}^{-1}$ ) and $\mathrm{BC}$ transport time (unit of $\mathrm{h}$ ) from the grid $h$ to the receptor site following the trajectory $l$, respectively, and $\left(\frac{D_{\mathrm{p}}}{D_{\mathrm{c}}}\right)_{\text {ini }}$ represents the initial value of the $D_{\mathrm{p}} / D_{\mathrm{c}}$ ratio of $\mathrm{BC}$ before transport (Fig. 4 ).

For a trajectory, $l, \mathrm{BC}$ particles pass through a series of grids (i.e., $h_{1}, h_{2}, h_{3}, \ldots$ ) to the receptor (i.e., $h_{n}$ ), the average $D_{\mathrm{p}} / D_{\mathrm{c}}$ ratio (i.e., $\left.\left(\frac{D_{\mathrm{p}}}{D_{\mathrm{c}}}\right)_{l}\right)$ of overall $\mathrm{BC}$ particles transported to the receptor site from various source origins (i.e., $h_{1}, h_{2}, h_{3}, \ldots, h_{i}, \ldots, h_{n}$ ) is determined by the massweighted $\left(\frac{D_{\mathrm{p}}}{D_{\mathrm{c}}}\right)_{h, l}$, which is expressed by Eq. (6):

$$
\left(\frac{D_{\mathrm{p}}}{D_{\mathrm{c}}}\right)_{l}=\sum_{h=1}^{\mathrm{TNG}_{l}}\left[\left(\frac{D_{\mathrm{p}}}{D_{\mathrm{c}}}\right)_{h, l} \times W_{h, l}\right]
$$

where $\mathrm{TNG}_{l}$ represents the total number of contributing grids to $\mathrm{BC}$ over the receptor site following the trajectory $l ; W_{h, l}$ represents the weighting factor of $\mathrm{BC}$ from the grid $h$, which is determined by the effective emission intensity (EEI; defined by $\mathrm{Lu}$ et al., 2012). The EEI represents the effective $\mathrm{BC}$ amount transported to the receptor site from the emission origins, taking into account the magnitude of $\mathrm{BC}$ emission from origin regions, the transport, hydrophobic-tohydrophilic transformation, as well as dry and wet depo- sitions during atmospheric transport. $W_{h, l}$ is calculated by Eq. (7):

$$
W_{h, l}=\frac{\mathrm{EEI}_{h, l}}{\sum_{h=1}^{\mathrm{TNG}_{l}} \mathrm{EEI}_{h, l}} .
$$

Following the algorithm developed by Lu et al. (2012), the EEI of BC transported the receptor site from the surface grid $h$ following a trajectory $l$ (i.e., $\mathrm{EEI}_{h, l}$ in Eq. 7) can be determined by Eq. (5):

$\mathrm{EEI}_{h, l}=E_{h} \times \mathrm{TE}_{h, l}$,

where $\mathrm{TE}_{h, l}$ represents the $\mathrm{BC}$ transport efficiency following the trajectory $l$, which is calculated following Eqs. (1)(4) shown in Lu et al. (2012). The TE is defined to quantify the transport ability of $\mathrm{BC}$ from origin regions to the receptor site based on transformation (i.e., hydrophobic-tohydrophilic BC) and removal processes of BC (i.e., dry and wet depositions) in the atmospheric.

Combining Eqs. (5)-(7), the $\left(\frac{D_{\mathrm{p}}}{D_{\mathrm{c}}}\right)$, can be calculated by Eq. (9):

$$
\begin{aligned}
& \left(\frac{D_{\mathrm{p}}}{D_{\mathrm{c}}}\right)_{l}= \\
& \sum_{h=1}^{\mathrm{TNG}_{l}}\left[\left(k E_{\mathrm{aver}, h, l} t_{h, l}+\left(\frac{D_{\mathrm{p}}}{D_{\mathrm{c}}}\right)_{\mathrm{ini}}^{3}\right)^{\frac{1}{3}} \times \frac{\mathrm{EEI}_{h, l}}{\sum_{h=1}^{\mathrm{TNG}_{l}} \mathrm{EEI}_{h, l}}\right] .
\end{aligned}
$$


In Eq. (9), two parameters (i.e., $\left(\frac{D_{\mathrm{p}}}{D_{\mathrm{c}}}\right)_{\text {ini }}$ and $k$ ) need to be retrieved. The $\left(\frac{D_{\mathrm{p}}}{D_{\mathrm{c}}}\right)_{\text {ini }}$ characterizes the $\mathrm{BC}$ aging degree near emissions. The parameter $k$ represents the rate coefficient of coating materials produced on the surface of $\mathrm{BC}$ by atmospheric aging such as condensation, coagulation and cloud process, which is influenced by meteorological factors, chemistry, aerosol phase state as well as other parameters (e.g., particle size).

The $\left(\frac{D_{\mathrm{p}}}{D_{\mathrm{c}}}\right)_{\text {ini }}$ value is estimated by the $\mathrm{BC}$ aging near different emission sources. In this work, the $D_{\mathrm{p}} / D_{\mathrm{c}}$ values of $\mathrm{BC}$ near the industrial, residential and traffic sources were prescribed as 1.4, 1.6 and 1.2 (Liu et al., 2014, 2017, 2015; Laborde et al., 2013; Healy et al., 2015; Kondo et al., 2011; Morgan et al., 2019; Pan et al., 2017; Ramnarine et al., 2019; Willis et al., 2016; Schwarz et al., 2008; Shi et al., 2019; Y. Wang et al., 2018). The $\left(\frac{D_{\mathrm{p}}}{D_{\mathrm{c}}}\right)_{\text {ini }}$ at the source origin (i.e., grid $h$ ) was taken as the mass-weighted values of different source types. Figure $\mathrm{S} 1$ shows that the $\left(\frac{D_{\mathrm{p}}}{D_{\mathrm{c}}}\right)_{\text {ini }}$ values in Beijing and its surrounding areas were dominated by $1.45-1.55$, which was agreed with the lowest 5 th percentile of the observed $D_{\mathrm{p}} / D_{\mathrm{c}}$ ratio of ambient BC-containing particles at a Beijing site (Table 1). This validated the $\left(\frac{D_{\mathrm{p}}}{D_{\mathrm{c}}}\right)_{\text {ini }}$ value used in the model calculation.

The aging rate coefficient $k$ is retrieved from in situ measurements. The $k$ value can be determined with an assumption that the simulated $D_{\mathrm{p}} / D_{\mathrm{c}}$ ratio of BC-containing particles was equal to the measured ones. It was noted that the simulated $\left(\frac{D_{\mathrm{p}}}{D_{\mathrm{c}}}\right)_{l}$ values, with an hourly temporal resolution, from Eq. (9) might not be equal to the observed values at a certain hour because some BC particles transported were not transported out of the observed site within $1 \mathrm{~h}$. To reduce the influence of the incomplete dispersion of ambient aerosols, the experimentally determined $k$ was calculated based on the observed $D_{\mathrm{p}} / D_{\mathrm{c}}$ ratio of $\mathrm{BC}$-containing particles during a period $\left(\left(\frac{D_{\mathrm{p}}}{D_{\mathrm{c}}}\right)_{\text {obs, }}\right)$, such as the mass-average values during a pollution episode and the whole campaign. In this work, the aging rate coefficient $k$ was calculated with the assumption that the $\left(\frac{D_{\mathrm{p}}}{D_{\mathrm{c}}}\right)_{\text {obs,p }}$ values was equal to the simulated $D_{\mathrm{p}} / D_{\mathrm{c}}$ ratio of $\mathrm{BC}$-containing particles over the receptors from various source origins during a period following various trajectories (i.e., $\left.\left(\frac{D_{\mathrm{p}}}{D_{\mathrm{c}}}\right)_{\mathrm{p}}\right)$.
Following Eqs. (5)-(7), $\left(\frac{D_{\mathrm{p}}}{D_{\mathrm{c}}}\right)_{\mathrm{p}}$ is calculated using Eq. (10):

$$
\left\{\begin{array}{l}
\left(\frac{D_{\mathrm{p}}}{D_{\mathrm{c}}}\right)_{\mathrm{p}}=\sum_{h=1}^{\mathrm{TNG}_{\mathrm{p}}}\left[\left(\frac{D_{\mathrm{p}}}{D_{\mathrm{c}}}\right)_{h, \mathrm{p}} \times W_{h, \mathrm{p}}\right] \\
\left(\frac{D_{\mathrm{p}}}{D_{\mathrm{c}}}\right)_{h, \mathrm{p}}=\left(k\left(\frac{\sum_{l=1}^{\mathrm{TNT}_{h, \mathrm{p}}} E_{\mathrm{aver}, h, l} t_{h, l}}{\mathrm{TNT}_{h, \mathrm{p}}}\right)+\left(\frac{D_{\mathrm{p}}}{D_{\mathrm{c}}}\right)_{\mathrm{ini}}^{3}\right)^{\frac{1}{3}} \\
W_{h, \mathrm{p}}=\frac{\mathrm{EEI}_{h, \mathrm{p}}}{\sum_{h=1}^{\mathrm{TNG}_{\mathrm{p}}} \mathrm{EEI}_{h, \mathrm{p}}}
\end{array}\right.
$$

where $\left(\frac{D_{\mathrm{p}}}{D_{\mathrm{c}}}\right)_{h, \mathrm{p}}$ represents the $D_{\mathrm{p}} / D_{\mathrm{c}}$ ratio of BC-containing aerosols transported to our observation site from a grid, $h$, during the period; $W_{h, \mathrm{p}}$ represents the weighting factor of $\mathrm{BC}$ from the grid $h$ to the receptor site during the period; $\mathrm{TNG}_{\mathrm{p}}$ represents the total number of contributing grids to $\mathrm{BC}$ over the receptor site during the period; $\mathrm{TNT}_{h, \mathrm{p}}$ represents the total number of trajectories passing through the grid $h$ during the period; and $\mathrm{EEI}_{h, \mathrm{p}}$ represents the EEI in the surface grid $h$ during our a period, which is calculated by Eq. (11) (Lu et al., 2012):

$\mathrm{EEI}_{h, \mathrm{p}}=E_{h} \times\left[\left(\sum_{l=1}^{\mathrm{TNT}_{h, \mathrm{p}}} \mathrm{TE}_{h, l}\right) / \mathrm{TNT}_{\mathrm{p}}\right]$,

where $\mathrm{TNT}_{h, \mathrm{p}}$ represents the total number of trajectories passing through the grid $h$ and $\mathrm{TNT}_{\mathrm{p}}$ represents the total number of back-trajectories originating at our site during the whole period. Figure 3 shows the TE density (TED) (defined as $\left(\sum_{l=1}^{\mathrm{TNT}_{h, \mathrm{p}}} \mathrm{TE}_{h, l}\right) / \mathrm{TNT}_{\mathrm{p}}$ in Eq. 11, Lu et al., 2012) and EEI on a $0.25^{\circ} \times 0.25^{\circ}$ grid during the episodes $1-4$ (Fig. 1a). The gridded EEI analysis revealed that BC particles over the Tsinghua site during the four episodes are from different source types, namely industrial and rural sources, urban and rural sources, urban and industrial sources as well as industrial source during episodes $1-4$, respectively. This indicated that the model parameters obtained from the BJNOV2014 measurement are representative. 
With the assumption that $\left(\frac{D_{\mathrm{p}}}{D_{\mathrm{c}}}\right)_{\mathrm{p}}=\left(\frac{D_{\mathrm{p}}}{D_{\mathrm{c}}}\right)_{\text {obs,p }}$, the experimentally determined $k$ was calculated by Eq. (12):

$$
\begin{aligned}
& k=\left[\left(\frac{D_{\mathrm{p}}}{D_{\mathrm{c}}}\right)_{\mathrm{obs}, \mathrm{p}}^{3}-\left(\frac{D_{\mathrm{p}}}{D_{\mathrm{c}}}\right)_{\mathrm{ini}}^{3}\right] \\
& \times \frac{\sum_{h=1}^{\mathrm{TNG}_{\mathrm{p}}} \mathrm{EEI}_{h, \mathrm{p}}}{\sum_{h=1}^{\mathrm{TNG}_{\mathrm{p}}}\left[\left(\frac{\sum_{l=1}^{\mathrm{TNT}_{h, \mathrm{p}}} E_{\mathrm{aver}, h, l} t_{h, l}}{\mathrm{TNT}_{h, \mathrm{p}}}\right) \times \mathrm{EEI}_{h, \mathrm{p}}\right]} .
\end{aligned}
$$

In this work, the $k$ value was calculated based on the measured $D_{\mathrm{p}} / D_{\mathrm{c}}$ ratios of $\mathrm{BC}$-containing particles during BJNOV2014 campaign period at the Tsinghua site $\left(40^{\circ} 00^{\prime} 17^{\prime \prime} \mathrm{N}, 116^{\circ} 19^{\prime} 34^{\prime \prime} \mathrm{E}\right)$ in Beijing. In order to obtain the $k$ value and then valid our models, the BJNOV2014 measurements were divided into two parts: the first two episodes (i.e., 17-24 November 2014) used to calculate the $k$ value and the last two episodes (i.e., 24-30 November 2014) used for model validation. Following the Eq. (12), the normalized aging rate coefficient $k$ was determined to have a value of $\sim 1.8 \times 10^{-4} \mathrm{t}^{-1} \mathrm{~h}^{-1}$. Correspondingly, the value of $k_{\text {aging }}$ in Eq. (1) is $\sim 17 \% \mathrm{~h}^{-1}$, which was comparable with the observation ones (Cheng et al., 2012; Zhang et al., 2018b).

To evaluate our model calculation of the mixing state of BC-containing particles over the site, the simulated $\left(\frac{D_{\mathrm{p}}}{D_{\mathrm{c}}}\right)_{\text {l }}$ values with an hourly temporal resolution are compared with the observed hourly $D_{\mathrm{p}} / D_{\mathrm{c}}$ ratio during 24-30 November 2014 (i.e., the last two episodes during the BJNOV2014 measurement). It is noted that the observed $D_{\mathrm{p}} / D_{\mathrm{c}}$ ratio at a certain hour is not only dominated by the aging degree of BC transported to the site at this time, but is also impacted by the aging degree of $\mathrm{BC}$ over the site several hours beforehand due to the incomplete dispersion of ambient aerosols within $1 \mathrm{~h}$. In this work, we averaged the simulated $\left(\frac{D_{\mathrm{p}}}{D_{\mathrm{c}}}\right)$, at a certain hour and within $n(n=0,2,4,6, \ldots)$ hours beforehand $\left(\left(\frac{D_{\mathrm{p}}}{D_{\mathrm{c}}}\right)_{\text {aver }, t}\right)$ to compare with the observed hourly $D_{\mathrm{p}} / D_{\mathrm{c}}$ ratio. $\left(\frac{D_{\mathrm{p}}}{D_{\mathrm{c}}}\right)_{\text {aver }, t}$ is calculated by Eq. (13):

$$
\left(\frac{D_{\mathrm{p}}}{D_{\mathrm{c}}}\right)_{\mathrm{aver}, t}=\frac{\sum_{l=t-n}^{t}\left(\frac{D_{\mathrm{p}}}{D_{\mathrm{c}}}\right)_{l}}{n+1} .
$$

Figure 5 shows an excellent agreement between the simulated and observed hourly $D_{\mathrm{p}} / D_{\mathrm{c}}$ ratios, with a difference of $\sim 3 \%$. The simulated $\left(\frac{D_{\mathrm{p}}}{D_{\mathrm{c}}}\right)_{\mathrm{aver}, t}$ values, with $n=2,4$, and 6 , exhibit a better correlation with the observed hourly $D_{\mathrm{p}} / D_{\mathrm{c}}$ ratio than those without considering the effect of BC
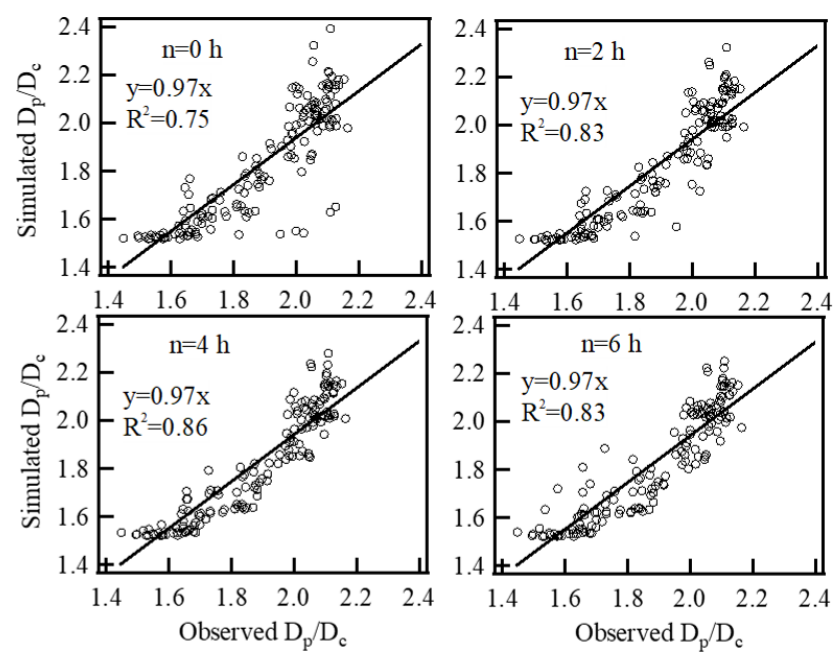

Figure 5. Comparison of the hourly $D_{\mathrm{p}} / D_{\mathrm{c}}$ ratio of BC between the model simulations and observations at our site with different $n$ values in Eq. (13) on 24-30 November 2014 at the Tsinghua site.

transported over our observation site within a few hours beforehand (i.e., $n=0$ ). When $n=4$, the linear relationship between the simulated and observed $D_{\mathrm{p}} / D_{\mathrm{c}}$ ratios exhibited the highest correlation coefficient (i.e., $R^{2}=0.86$ ), and thereby this value was used in the following calculation.

\section{Results and discussion}

\subsection{Simulating BC mixing state with a high time resolution}

Following Eqs. (9) and (13), we calculated the hourly $D_{\mathrm{p}} / D_{\mathrm{c}}$ ratios of BC-containing particles during the BJOCT2014, BJSEP2015 and BJAUG2015 measurement periods. Figure 6 shows that the simulated $D_{\mathrm{p}} / D_{\mathrm{c}}$ values of BC-containing particles exhibit significant changes with pollution levels (i.e., the $\mathrm{PM}_{2.5}$ and $\mathrm{rBC}$ concentrations), revealing that our model with a high time resolution can simulate the evolution of the $\mathrm{BC}$ aging degree during a pollution episode. The simulation results showed that under pollution conditions, not only did the $\mathrm{BC}$ mass concentrations increase, but the aging degree of BC-containing particles was also enhanced. This identified the amplification of $\mathrm{BC}$ light absorption associated with air pollution due to more coating material on the $\mathrm{BC}$ surface (Zhang et al., 2018c).

Simulation of $\mathrm{BC}$ mixing state with a high time resolution is important to evaluate the effect on air quality. The effect of $\mathrm{BC}$ on air quality depends on both the mass concentration and the aging degree of BC. Simultaneous increase in the mass concentration and aging degree of $\mathrm{BC}$ associated with air pollution could suppress the PBL by the dome effect (Ding et al., 2016). In China, the air pollution often starts rapidly within several hours (Zheng et al., 2016). It is neces- 

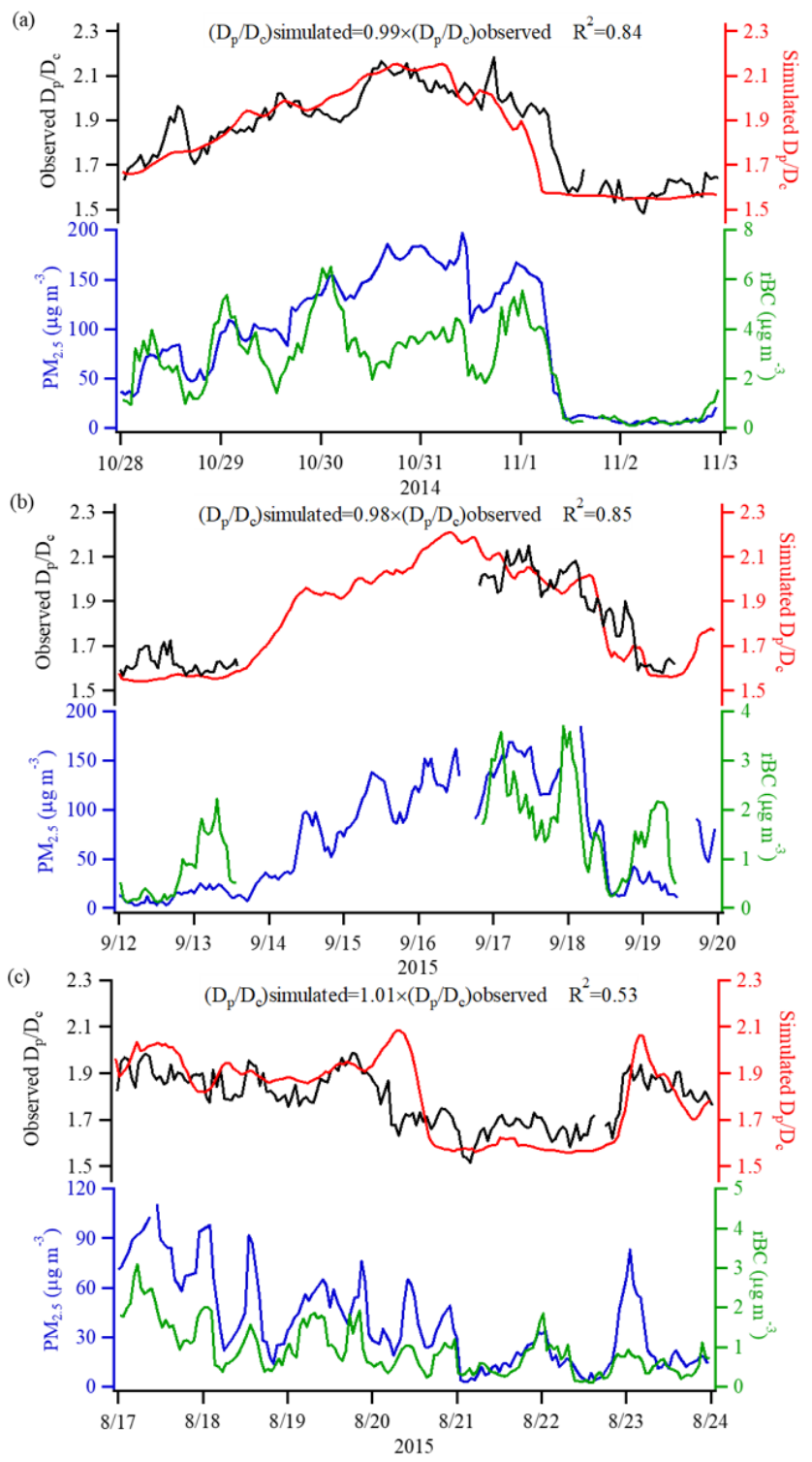

Figure 6. Time series of the observed $D_{\mathrm{p}} / D_{\mathrm{c}}$ ratio, simulated $D_{\mathrm{p}} / D_{\mathrm{c}}$ ratio, and $\mathrm{PM}_{2.5}$ and $\mathrm{rBC}$ concentrations during the (a) BJOCT2014, (b) BJSEP2015 and (c) BJAUG2015 measurement periods.

sary to understand the hourly aging degree of BC-containing particles for better exploring the effect of $\mathrm{BC}$ on air quality. Our model calculation can provide $\mathrm{BC}$ aging degree (i.e., $D_{\mathrm{p}} / D_{\mathrm{c}}$ ratio) with a fine temporal resolution of $1 \mathrm{~h}$.

The simulated $\mathrm{BC}$ mixing state with high time resolution during different measurement periods was used to reveal that our models could be generally applied. Although the model is established based on the BJNOV2014 measurement (17-30 November 2014), the model calculation can be applicable to other months under pollution periods (i.e., October 2014, September 2015, and August 2015). Figure 6 reveals an excellent agreement between the simulated and ob-

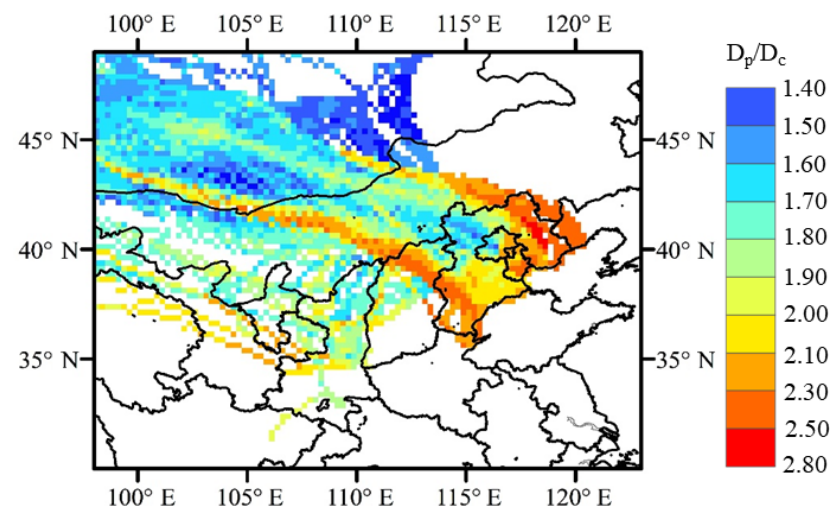

Figure 7. Aging degree (i.e., $D_{\mathrm{p}} / D_{\mathrm{c}}$ ) of $\mathrm{BC}$ particles as they are transported to the receptor site $\left(40^{\circ} 00^{\prime} 17^{\prime \prime} \mathrm{N}, 116^{\circ} 19^{\prime} 34^{\prime \prime} \mathrm{E}\right)$ from emission origins $\left(0.25^{\circ} \times 0.25^{\circ}\right)$ during the BJNOV2014 campaign period. The gridded $D_{\mathrm{p}} / D_{\mathrm{c}}$ ratio was calculated by Eq. (11).

served hourly $D_{\mathrm{p}} / D_{\mathrm{c}}$ ratio for the BJOCT2014, BJSEP2015 and BJAUG2015 measurements. During these measurement periods, the linear relationship between the simulated $D_{\mathrm{p}} / D_{\mathrm{c}}$ ratio and the observed values shows slopes of $0.98-1.01$, with a correlation coefficient $\left(R^{2}\right)$ of $0.53-0.85$. A good correlation further demonstrated the validity of our model for calculating the $\mathrm{BC}$ mixing state during atmospheric transport. Accurate simulations for the different measurement periods identify the generalness of our model, especially under polluted environments.

\subsection{BC mixing state during the atmospheric transport process}

\subsubsection{Aging degree of $\mathrm{BC}$ from emission origins to receptor sites}

Using our models, we investigated the aging process of $\mathrm{BC}$ containing particles transported from different spatial origins to the receptor (i.e., the Tsinghua site, Beijing) during the BJNOV2014 measurement period. The origin-resolved $\left(0.25^{\circ} \times 0.25^{\circ}\right) D_{\mathrm{p}} / D_{\mathrm{c}}$ ratio of $\mathrm{BC}$-containing particles over the receptor site was calculated using Eq. (11), shown in Fig. 7. The BC-containing particles from various spatial origins exhibited significant differences in their mixing state, with the $D_{\mathrm{p}} / D_{\mathrm{c}}$ ratio in the range of 1.4-2.8 as they reached the Tsinghua site. The $D_{\mathrm{p}} / D_{\mathrm{c}}$ ratio of $\mathrm{BC}$ from the polluted regions (i.e., southern Heibei, northeastern Hebei and Tianjin) could be up to $\sim 2.3-2.8$, which characterized the mixing state of fully aged BC in the North China Plain (NCP). These fully aged $\mathrm{BC}$ particles played an important role in regional light absorption (Gustafsson and Ramanathan, 2016; Peng et al., 2016). The high $D_{\mathrm{p}} / D_{\mathrm{c}}$ ratio $(\sim 2.3-2.8)$ of $\mathrm{BC}$ transported to our site was consistent with the mixing state of fully aged $\mathrm{BC}$ particles $\left(D_{\mathrm{p}} / D_{\mathrm{c}}\right.$ ratio $\left.\sim 2.5\right)$ in Beijing reported by Peng et al. (2016), implying reliable values of the gridded $D_{\mathrm{p}} / D_{\mathrm{c}}$ ratio from our model calculation. 

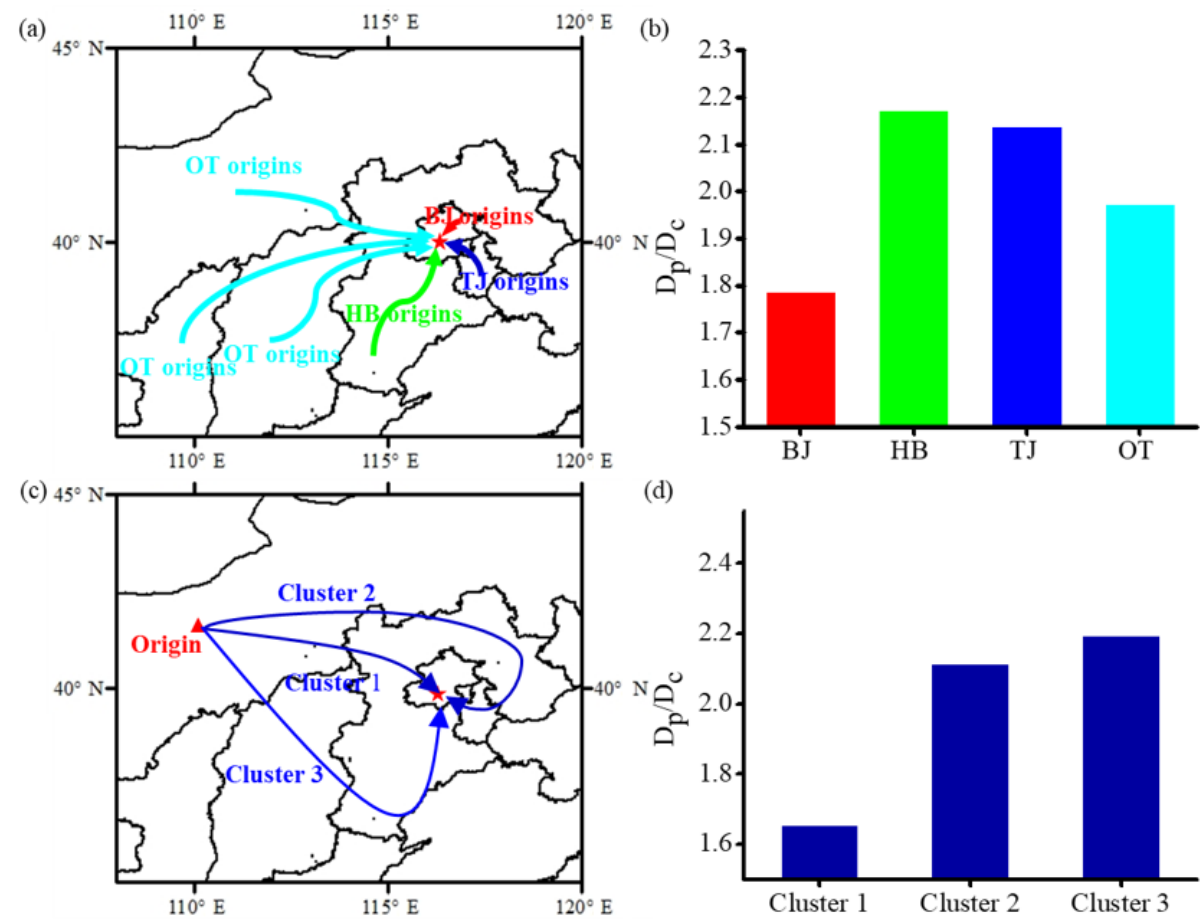

Figure 8. BC aging from emission origins to the receptor site $\left(40^{\circ} 00^{\prime} 17^{\prime \prime} \mathrm{N}, 116^{\circ} 19^{\prime} 34^{\prime \prime} \mathrm{E}\right.$; marked with a red star) during the BJNOV2014 measurement period: (a) classification of the BC emission source regions based on political boundaries (i.e., the Beijing source regions (BJ origins), Hebei source regions (HB origins), Tianjin source regions (TJ origins) and other source regions (OT origins)); (b) aging degree (i.e., $D_{\mathrm{p}} / D_{\mathrm{c}}$ ) of $\mathrm{BC}$ particles emitted from the four source regions as they are transported to the receptor site; (c) conceptual scheme of trajectories that pass through low-emission regions (cluster 1), medium-emission regions (cluster 2) and high-emission regions (cluster 3) as they transport from clean origins (e.g., Inner Mongolia) to the receptor site; and (d) the degree of aging of BC reaching the receptor site through different trajectories (i.e., clusters 1,2 and 3 shown in c).

In this work, we classified the spatial emission sources of BC-containing particles over the receptor site into local (or Beijing (i.e., BJ origin), shown in Fig. 8a) and non-local (i.e., non-Beijing) origins based on political boundaries. The non-local origins were further divided into Hebei, Tianjin and other origins (i.e., HB, TJ or OT origins, respectively, as shown in Fig. 8a). Based on the gridded $D_{\mathrm{p}} / D_{\mathrm{c}}$ ratio shown in Fig. 7, the $D_{\mathrm{p}} / D_{\mathrm{c}}$ ratios of BC-containing particles from Beijing, Hebei, Tianjin and other regions during the campaign period were estimated to be 1.8, 2.2, 2.1 and 2.0 , respectively (Fig. $8 \mathrm{~b}$ ). Figure $2 \mathrm{~b}$ reveals that more intensive emission regions of $\mathrm{BC}$ are located in southern Beijing, southern Hebei, northeastern Hebei and Tianjin, which dominated $\mathrm{BC}$ amount over the receptor site during the campaign period (Fig. 3). The EEI analysis (Fig. 3) shows that BCcontaining particles transported to the site during the campaign period mainly originate from Beijing, Hebei, Tianjin, Inner Mongolia, Shanxi and Shaanxi (the political boundaries of these regions are shown in Fig. 2a).

The contributions of different emission origins to the $\mathrm{BC}$ amount over the receptor site during the BJNOV2014 measurement period were estimated by EEI analysis. BC transported to the site was dominated by Hebei and Beijing as the major source regions, accounting for $\sim 40.2 \%$ and $\sim 40.0 \%$ of the total amount transported, respectively. In terms of non-local (i.e., non-Beijing) origins, the contribution of BC from Hebei was significantly higher than that from Tianjin $(\sim 4.2 \%)$ and others $(\sim 15.5 \%)$ due to more intensive emissions and a larger region in Hebei Province. Approximately $60 \%$ of BC from non-local origins (i.e., Hebei, Tianjin and others) indicated the importance of atmospheric transport to $\mathrm{BC}$ concentrations during polluted environments. During the campaign period, the average $\mathrm{BC}$ mass concentration was $\sim 4.0 \mu \mathrm{g} \mathrm{m}^{-3}$ (Fig. 1b). Based on EEI analysis, the mass concentrations of local (i.e., Beijing) and non-local (i.e., nonBeijing) $\mathrm{BC}$ at the observed site were estimated to be $\sim 1.6$ and $\sim 2.4 \mu \mathrm{g} \mathrm{m}^{-3}$, respectively.

Atmospheric transport not only played an important role in $\mathrm{BC}$ mass concentration in Beijing under polluted environments, but also controlled BC aging. During the investigation period, the $D_{\mathrm{p}} / D_{\mathrm{c}}$ ratio of non-local (i.e., non-Beijing) BC over the site was $\sim 2.1$, which was greater than that of local (i.e., Beijing) BC $(\sim 1.8)$. The higher aging degree of nonlocal $\mathrm{BC}$ could be attributed to the longer transport time and larger emissions from non-local origins. As more intensive emission sources (i.e., polluted regions), Hebei and Tianjin 
were identified as the two largest contributing regions for the $\mathrm{BC}$ mixing state at the site (Figs. 7 and $8 \mathrm{~b}$ ). When BC particles were emitted from Hebei and Tianjin and then transported to the receptor site, their $D_{\mathrm{p}} / D_{\mathrm{c}}$ ratios could reach up to 2.2 and 2.1, respectively, which were larger than that from other non-local origins (i.e., cleaner regions). This could be due to more pollutant emission from southern Hebei, northeastern Hebei and Tianjin than that from other regions (i.e., Inner Mongolia). The results revealed that $\mathrm{BC}$ particles emitted from polluted regions would exhibit a higher aging degree during atmospheric transport, which is most likely attributed to more rapid aging due to more co-emitted coating precursors (Peng et al., 2016).

On the other hand, high emission origins (e.g., southern Hebei, northeastern Hebei and Tianjin) also affect the aging process of $\mathrm{BC}$ particles that pass through these regions. When $\mathrm{BC}$ particles are emitted from a clean origin and then pass through high emission regions (e.g., southern Hebei) to the receptor site (e.g., cluster 3 shown in Fig. 8c), their $D_{\mathrm{p}} / D_{\mathrm{c}}$ ratio could reach $\sim 2.2$ (Fig. $8 \mathrm{~d}$ ). However, the emitted $\mathrm{BC}$ particles from the clean origin passing through a series of clean origins (e.g., cluster 1 shown in Fig. 8c) show a lower $D_{\mathrm{p}} / D_{\mathrm{c}}$ ratio $(\sim 1.6$, Fig. $8 \mathrm{~d})$ as they reach the site. This difference identifies the important role of extensive emission regions (e.g., southern Hebei) in the atmospheric aging process of BC particles emitted from other clean regions (e.g., Inner Mongolia). When $\mathrm{BC}$ particles passed through these polluted regions, their aging degree could be accelerated due to high pollutant emission.

\subsubsection{Emission dependence}

As discussed above, the aging process of $\mathrm{BC}$ particles during atmospheric transport was closely associated with emissions from regions through which they pass. To investigate the dependence of the BC mixing state during atmospheric transport, we normalized the current emissions obtained from the MIX inventory as a unit and set the scenarios of BC emissions reduced by $20 \%, 40 \%, 50 \%, 60 \%$, and $80 \%$ (i.e., normalized emissions as $0.8,0.6,0.5,0.4$, and 0.2 , respectively, shown in Fig. 9).

Figure $9 \mathrm{a} 1$ shows that the $D_{\mathrm{p}} / D_{\mathrm{c}}$ ratios of local (i.e., Beijing) $\mathrm{BC}$, non-local (i.e., non-Beijing) $\mathrm{BC}$ and total $\mathrm{BC}$ (including both local and non-local BC) transported to the site were proportional to the emissions, with slopes of $0.55,0.26$ and 0.44 , respectively. The slope values revealed that the relative increase or decrease in the $D_{\mathrm{p}} / D_{\mathrm{c}}$ ratio with emission change for non-local $\mathrm{BC}$ was $\sim 2$ times that of local $\mathrm{BC}$. This result revealed that the mixing state of non-local $\mathrm{BC}$ was more sensitive to emission change than that of local BC. Therefore, emission reduction was more effective in lowering the aging degree of non-local $\mathrm{BC}$ compared with that of local BC. For example, when BC emissions were reduced by $50 \%$, the $D_{\mathrm{p}} / D_{\mathrm{c}}$ ratios of non-local $\mathrm{BC}$, local $\mathrm{BC}$ and total $\mathrm{BC}$ at our site decreased by $14 \%, 7 \%$ and $11 \%$, re- spectively. A greater reduction in the aging degree of non$\mathrm{BC}$ particles could be attributed to most of the non-local $\mathrm{BC}(\sim 75 \%)$ from high emission origins (i.e., the southern Hebei, northeastern Hebei and Tianjin regions). The originresolved $D_{\mathrm{p}} / D_{\mathrm{c}}$ ratio of $\mathrm{BC}$ transported to the site during the campaign period shown in Fig. 7 indicated that a greater reduction in aging degree would be found for $\mathrm{BC}$ from higher emission regions, such as southern Hebei, northeastern Hebei and Tianjin, which revealed the benefits of emission controls in extensive emission regions. The results identified the dependence of the $\mathrm{BC}$ aging process during atmospheric transport on emissions, especially for non-local $\mathrm{BC}$ from high emission origins.

To further evaluate the change in the mixing state of $\mathrm{BC}$ at the site from local (i.e., Beijing) and non-local (i.e., nonBeijing) emissions, we simulated the origin-resolved $D_{\mathrm{p}} / D_{\mathrm{c}}$ ratio of $\mathrm{BC}$ over the receptor site, only considering the changes in local (Fig. 9a2) or non-local (Fig. 9a3) emissions. It is noted that the mixing state of total $\mathrm{BC}$ at the receptor site not only depended on the respective $D_{\mathrm{p}} / D_{\mathrm{c}}$ ratio of local and non-local BC, but also on their contributions to the total BC amount. When only altering local or non-local emissions in the simulations, the contributions of various source origins to the $\mathrm{BC}$ amount at our site would be changed.

When the changes in only local emissions were included in our simulations, the mixing state of total $\mathrm{BC}$ (including both local (i.e., Beijing) and non-local BC (i.e., non-Beijing)) at the observed site was slightly sensitive to emissions. Figure $9 \mathrm{a} 2$ presents the linear change in the $D_{\mathrm{p}} / D_{\mathrm{c}}$ ratio of total $\mathrm{BC}$ with changing local emissions, with a slope of 0.07 , which is significantly smaller than that (0.44) for the cases of changing both local and non-local emissions (Fig. 8a1). Taking $50 \%$ of the reduction in local emissions as an example, the $D_{\mathrm{p}} / D_{\mathrm{c}}$ ratio of total BC at our site only decreased by $2 \%$. Meanwhile, $50 \%$ of the local emission reduction resulted in $\sim 5.0 \%$ and $\sim 4.6 \%$ of the decreases in the $D_{\mathrm{p}} / D_{\mathrm{c}}$ ratio for local and non-local $\mathrm{BC}$, respectively. The reductions in the $D_{\mathrm{p}} / D_{\mathrm{c}}$ ratio of local and non-local $\mathrm{BC}$ were larger than that in total BC $(\sim 2 \%)$, which was due to the increase in the contributions of non-local BC (characterized by a larger $D_{\mathrm{p}} / D_{\mathrm{c}}$ ratio compared to local $\mathrm{BC}$ ) with a local emission reduction. The results showed that altering local emissions had a slight effect on the BC mixing state at our site during the investigated period (i.e., under a polluted environment) due to a slight change in the aging degree of non-local BC.

In terms of non-local (i.e., non-Beijing) emission change, the response of the mixing state of total $\mathrm{BC}$ at our site to emission changes was more significant than that for the case of local (i.e., Beijing) emission change. The linear correlation between the $D_{\mathrm{p}} / D_{\mathrm{c}}$ ratio of total $\mathrm{BC}$ and normalized non-local emission (i.e., 0.2-1) shown in Fig. 9a3 exhibited a slope of 0.28 , which was markedly greater than that $(0.07)$ in the case of local emission change (Fig. 9a2). Figure 9a3 shows that the slope for total BC (i.e., 0.28) was similar to that (i.e., 0.31) for non-local $\mathrm{BC}$, indicating that the varia- 

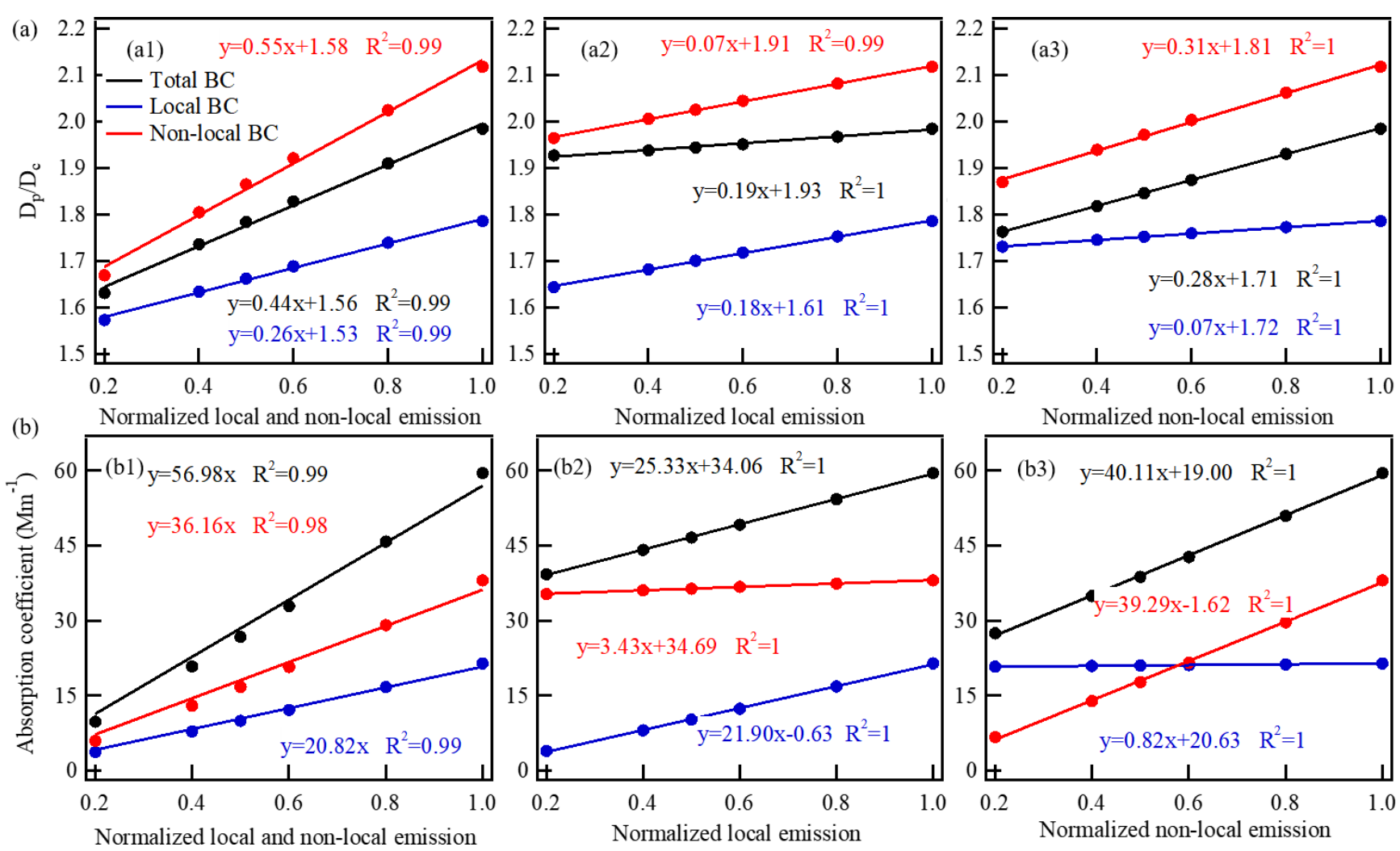

Figure 9. Variations in the (a) $D_{\mathrm{p}} / D_{\mathrm{c}}$ ratio and (b) light absorption coefficient for total, local and non-local BC over the site with normalized emissions. The current emissions obtained from the MIX inventory (Fig. 2b) were normalized as a unit and the emissions reductions of $20 \%$, $40 \%, 50 \%, 60 \%$, and $80 \%$ corresponded to the normalized emissions as 0.8, 0.6, 0.5, 0.4, and 0.2, respectively. (a1) and (b1) represent the simulations for the case of both local and non-local emission variations, respectively; (a2) and (b2) represent the simulations for the case of only local emissions variations; and (a3) and (b3) represent the simulations for the case of only non-local emissions variations. The light absorption coefficient of $\mathrm{BC}$ was estimated by the $\mathrm{BC}$ mass concentrations, the mass absorption cross section of $\mathrm{BC}\left(7.5 \mathrm{~m}^{2} \mathrm{~g}^{-1}\right.$ at $550 \mathrm{~nm}$ ) and the $D_{\mathrm{p}} / D_{\mathrm{c}}$ ratio. When the normalized emissions of total BC were equal to 1 , the average mass concentration of total $\mathrm{BC}$ was $\sim 4.0 \mu \mathrm{g} \mathrm{m}^{-3}$, which was obtained by measurements during the campaign period. The mass concentration of local and non-local BC can be further calculated based on their EEI contributions (i.e., $\sim 1.6 \mu \mathrm{g} \mathrm{m}^{-3}$ for local BC and $\sim 2.4 \mu \mathrm{g} \mathrm{m}^{-3}$ for non-local BC). Based on the linear decrease in $\mathrm{BC}$ mass concentration with emission reduction, the mass concentrations of total, local and non-local $\mathrm{BC}$ for different emission cases were calculated.

tion in the $\mathrm{BC}$ mixing state at our site during the investigated period (i.e., under a polluted environment) was controlled by the emission change in non-local BC. This result could be attributed to more aged $\mathrm{BC}$ particles being mainly from non-local regions (southern Hebei, northeastern Hebei and Tianjin). These results indicated that the $\mathrm{BC}$ mixing state at our site was dominated by non-local emissions (in particular polluted regions with intensive emission), identifying the importance of atmospheric transport in the $\mathrm{BC}$ mixing state in Beijing during polluted periods.

\subsection{BC light absorption in the atmosphere}

$\mathrm{BC}$ light absorption depends on both the mass concentration and mixing state of $\mathrm{BC}$. The light absorption of $\mathrm{BC}$ can be characterized by multiplying EEI by the $D_{\mathrm{p}} / D_{\mathrm{c}}$ ratio (i.e., $\mathrm{EEI} \times D_{\mathrm{p}} / D_{\mathrm{c}}$ ). In this study, the origin-resolved EEI $\times D_{\mathrm{p}} / D_{\mathrm{c}}$ values represent the light absorption levels of $\mathrm{BC}$ particles as they were transported to the receptor site from various source origins $\left(0.25^{\circ} \times 0.25^{\circ}\right)$. Figure 10a displays the originresolved EEI $\times D_{\mathrm{p}} / D_{\mathrm{c}}$ values during the campaign period. High light-absorption levels of $\mathrm{BC}$ were mainly from the local Beijing area, southern Hebei, northeastern Hebei and Tianjin, resulting from high $\mathrm{BC}$ emissions and strong BC aging in these regions.

The origin-resolved EEI $\times\left(D_{\mathrm{p}} / D_{\mathrm{c}}\right)$ values revealed the contributions of $\mathrm{BC}$ from different source regions to light absorption at the site (Fig. 10b). During the investigated period (i.e., polluted period) in Beijing, Hebei Province was the largest contributing region, accounting for $\sim 44 \%$ of BC light absorption transported to the observed site during the campaign period. Local Beijing was responsible for $\sim 36 \%$ of the light absorption of $\mathrm{BC}$ at the site, which was lower than the contribution from Hebei. In total, $\sim 64 \%$ of BC light 


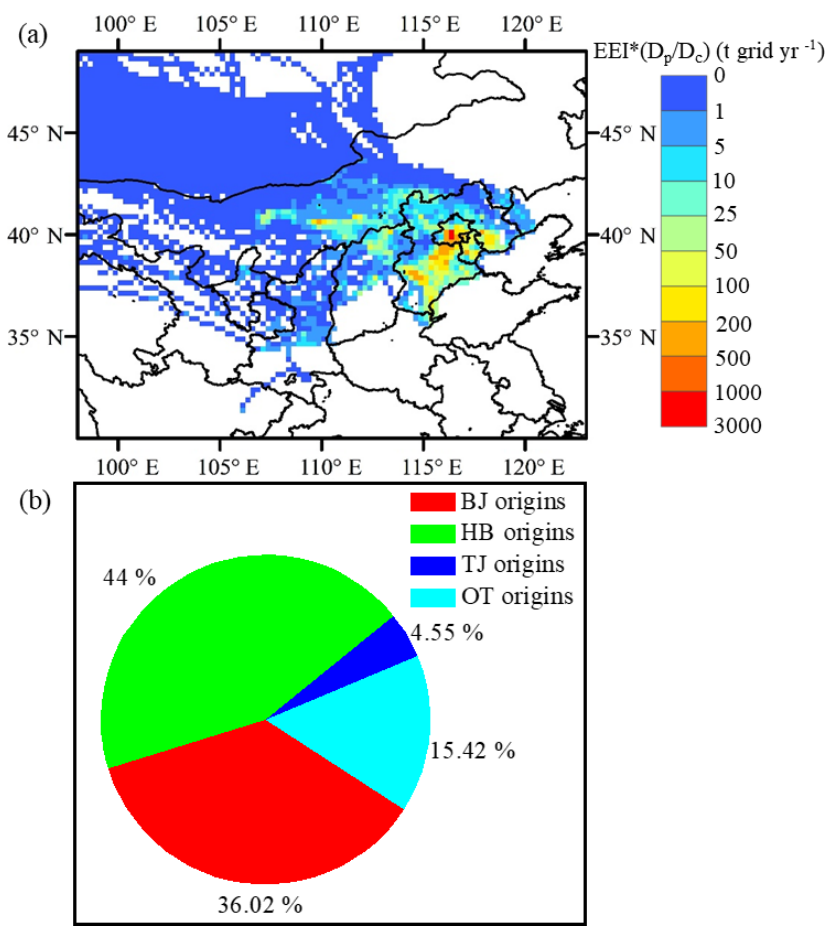

Figure 10. (a) Spatial distribution $\left(0.25^{\circ} \times 0.25^{\circ}\right.$ resolution $)$ for light absorption levels (i.e., $\left.\mathrm{EEI} \times\left(D_{\mathrm{p}} / D_{\mathrm{c}}\right)\right)$ of $\mathrm{BC}$ as it is transported to the receptor site $\left(40^{\circ} 00^{\prime} 17^{\prime \prime} \mathrm{N}, 116^{\circ} 19^{\prime} 34^{\prime \prime} \mathrm{E}\right)$ from various source origins. (b) Contributions of different source regions to BC light absorption at the receptor site. The classification of source regions based on political boundaries is shown in Fig. 8a. The BJ, HB, TJ and OT origins represent spatial sources of emitted $\mathrm{BC}$ transported to the receptor site from Beijing, Hebei, Tianjin and other regions, respectively.

absorption at the receptor site was contributed by non-local (i.e., non-Beijing) $\mathrm{BC}$ source origins, reflecting the importance of atmospheric transport for the light absorption of $\mathrm{BC}$ in Beijing during polluted periods. The contribution of nonlocal origins to $\mathrm{BC}$ light absorption at our site was larger than that to BC mass concentration $(\sim 60 \%$, as quantified by the EEI analysis), which was due to the higher aging degree $\left(D_{\mathrm{p}} / D_{\mathrm{c}}\right.$ ratio of $\left.\sim 2.12\right)$ of non-local BC compared to that of local BC $\left(D_{\mathrm{p}} / D_{\mathrm{c}}\right.$ ratio of $\left.\sim 1.78\right)$. If the difference between the mixing states of local and non-local BC is not considered, the effect of atmospheric transport on $\mathrm{BC}$ light absorption in Beijing during the polluted period would be underestimated. The results revealed that the $\mathrm{BC}$ aging process during atmospheric transport strengthens the importance of emissions from surrounding areas (e.g., Hebei and Tianjin) for BC light absorption in Beijing during polluted periods.

The strong dependence of both the mass concentrations and mixing states of $\mathrm{BC}$ on emissions indicates that emission reduction could significantly lower light absorption and thus weaken the effect of $\mathrm{BC}$ on air quality and climate, especially during polluted periods. A linear decrease in BC light ab- sorption with emission reductions was found (Fig. 9b). When both local (i.e., Beijing) and non-local (i.e., non-Beijing) BC emissions were reduced (Fig. 9b1), the change in light absorption for non-local $\mathrm{BC}$ was much more significant than that for local BC. For the case of a $50 \%$ reduction in both local and non-local $\mathrm{BC}$ emissions, the light absorption of total BC, local BC and non-local BC decreased by $55 \%, 53 \%$ and $56 \%$, respectively (Fig. 9b1). An extra decrease of $\sim 6 \%$ in light absorption for non-local BC was greater than that $(\sim 3 \%)$ for local BC, which could be attributed to a much greater reduction in the aging degree (i.e., $D_{\mathrm{p}} / D_{\mathrm{c}}$ ratio) of non-local BC (Fig. 9a1). Compared with local BC, a much greater decrease in the light absorption of non-local $\mathrm{BC}$ implied that the emission reduction from non-Beijing sources rather than Beijing sources achieved many more benefits in terms of the BC effect in Beijing. This result also revealed that the emissions reduction of the surrounding areas of Beijing not only brought less $\mathrm{BC}$, but also lowered the $\mathrm{BC}$ mixing state, which enhanced the decrease in $\mathrm{BC}$ light absorption in Beijing.

The analyses of only reducing local emissions or non-local emissions further identified the importance of emission reduction of non-Beijing sources to weaken BC light absorption in Beijing during polluted periods. For the case of local (i.e., Beijing) emissions reduction (Fig. 9b2), the reduction in $\mathrm{BC}$ light absorption was significantly smaller than that for the case of non-local (i.e., non-Beijing) emissions reduction (Fig. 9b3), revealing that emissions reduction in nonBeijing sources played a more important role in decreasing $\mathrm{BC}$ light absorption in Beijing. For example, when emissions were reduced by $50 \%$ for local and non-local origins, the BC light absorption at the site decreased by $21 \%$ and $35 \%$, respectively. A greater decrease in BC light absorption in Beijing with non-local emissions reduction resulted from larger contributions of non-Beijing source emissions (especially for polluted regions, such as southern Hebei, northeastern Hebei and Tianjin) to both the mass concentration and mixing state of $\mathrm{BC}$ over the site. Moreover, the extra reduction in $\mathrm{BC}$ light absorption in Beijing caused by weakening of the $\mathrm{BC}$ aging degree was also greater under non-Beijing emissions reduction compared with that under Beijing emissions reduction (e.g., $\sim 5 \%$ and $1 \%$ extra reductions for the cases of $50 \%$ reductions in non-local and local emissions, respectively). The important contribution of emission reduction of non-Beijing sources to decrease in $\mathrm{BC}$ light absorption in Beijing under polluted environments was mainly due to a significant decrease in both $\mathrm{BC}$ amount and its aging degree in Beijing caused by emission reduction of polluted regions (e.g., southern Hebei, northeastern Hebei and Tianjin). This suggested that the efforts to weaken the influence of $\mathrm{BC}$ on air pollution and climate change should pay more attention to emissions reduction in polluted regions. 


\section{Discussion}

In this study, a rather simplified scheme was adopted where the aging rate is assumed to be proportional to the emissions without detailed consideration of the effects of temperature, particle sizes, phase state, hygroscopicity and chemistry (Riemer et al., 2009; Cheng et al., 2008, 2012, 2015; $\mathrm{Mu}$ et al., 2018). Actually, these factors can influence the model parameter of an aging rate coefficient. Our simulations strongly depend on the emission, initial value of the $D_{\mathrm{p}} / D_{\mathrm{c}}$ ratio and aging rate coefficient. Accurate $\left(\frac{D_{\mathrm{p}}}{D_{\mathrm{c}}}\right)_{\text {ini }}$ values require more measurements of the mixing state of freshly emitted BC-containing particles. In this work, the experimentally determined $k$ value was derived from the observations during the pollution periods in autumn/winter measured in Beijing. In order to extend the application of our model in other seasons (e.g., summer) and sites, further work requires one to understand whether and how the model parameters (i.e., aging rate coefficient and the initial value of the $D_{\mathrm{p}} / D_{\mathrm{c}}$ ratio) vary at different seasons and sites. In terms of the aging rate coefficient in summer (Cheng et al., 2012; Zhang et al., 2018b), the measurements at two suburban sites (Xianghe and Yufa) in the NCP showed a pronounced diurnal cycle in the range of $0.2 \% \mathrm{~h}^{-1}-20 \% \mathrm{~h}^{-1}$ with a maximum at noontime due to stronger photochemistry. The $k_{\text {aging }}$ around noontime in summer was comparable with that $\left(\sim 17 \% \mathrm{~h}^{-1}\right)$ in autumn/winter. However, other times, especially nighttime in summer, are significantly smaller. For the $\left(\frac{D_{\mathrm{p}}}{D_{\mathrm{c}}}\right)_{\text {ini }}$, its variety is due to different dominated sources of $\mathrm{BC}$ in different seasons and sites, which can be estimated by the $\mathrm{BC}$ aging degree near different types of emission sources (e.g., industrial, residential and traffic emissions). Figure S1 shows the distinct $\left(\frac{D_{\mathrm{p}}}{D_{\mathrm{c}}}\right)_{\mathrm{ini}}$ values at different sites in November. The $\left(\frac{D_{\mathrm{p}}}{D_{\mathrm{c}}}\right)_{\text {ini }}$ values are also season dependent. For example, the BC particles in Beijing in summer are controlled by traffic and industrial emissions with a smaller higher $D_{\mathrm{p}} / D_{\mathrm{c}}$ ratio near sources, but the major sources of BC in autumn/winter are industrial and residential emissions with higher $\left(\frac{D_{\mathrm{p}}}{D_{\mathrm{c}}}\right)_{\text {ini }}$ (D. Liu et al., 2019; H. Liu et al., 2019). Lower values both of the aging rate coefficient and the initial value of the $D_{\mathrm{p}} / D_{\mathrm{c}}$ ratio would lead to thinner coatings of $\mathrm{BC}$ in summer compared with those in autumn/winter in the NCP, which was consistent with observations in Beijing (D. Liu et al., 2019).

The retrieved aging rate coefficient $k_{\text {aging }}$ indicated that $\mathrm{BC}$ particles under polluted environments in autumn/winter in the NCP underwent fast aging during atmospheric transport. The retrieved $k_{\text {aging }}$ with a value of $\sim 17 \% \mathrm{~h}^{-1}$ used in our models is comparable with the observed values at other suburban sites in the NCP, namely up to $\sim 20 \% \mathrm{~h}^{-1}$ and $\sim 21 \% \mathrm{~h}^{-1}$ at the Yufa site and Xianghe site, respectively (Cheng et al., 2012; Zhang et al., 2018b). However, the aging rate coefficient commonly used in other models $\left(1 \% \mathrm{~h}^{-1}-5 \% \mathrm{~h}^{-1}\right)$ was significantly smaller than that used in our model (Cooke and Wilson, 1996; Jacobson, 2001; Koch, 2001; Lohmann et al., 2000), indicating that the values used in previous models derived in developed countries (Moteki et al., 2007; Shiraiwa et al., 2007) could not represent the characteristic of $\mathrm{BC}$ aging processes in China. A similar conclusion was also drawn by Peng et al. (2016) using an environment chamber, namely the timescale of $\mathrm{BC}$ aging to achieve high absorption enhancement $(\sim 2.4)$ displaying significant distinction between urban cities in Beijing $(\sim 4.6 \mathrm{~h})$ and Houston $(\sim 18 \mathrm{~h})$. A higher aging rate coefficient suggested the $\mathrm{BC}$ aging under polluted environments in the $\mathrm{NCP}$ is most likely dominated by a condensation process during atmospheric transport, taking into account a clear difference between the timescale of BC aging by condensation (2-8h) and coagulation (10-40 h) (Riemer et al., 2004).

More aged BC aloft increases atmospheric stability, which suppressed the development boundary layer and suppresses or enhances the formation of different types of clouds (Barbaro et al., 2013; Ding et al., 2016; Jacobson, 1998; Zdunkowski et al., 1976; Wendisch et al., 2008; Z. Wang et al., 2018). Our simulations showed that the aging degree of BC from atmospheric transport along with polluted air masses was significantly higher than that of local BC under polluted conditions, implying that the light absorption capability (i.e., mass cross section of BC-containing particles including coating materials on $\mathrm{BC}$ surface) of $\mathrm{BC}$ in the upper PBL would be higher than that of BC in the lower PBL. This characteristic favored the formation of the inversion layer due to more heating in the upper PBL under polluted conditions (Ding et al., 2016; Z. Wang et al., 2018), which consequently depressed PBL development. In China, air pollution generally occurs at the regional scale due to atmospheric transport (Sun et al., 2014; L. Wang et al., 2014; Yang et al., 2015; Zheng et al., 2015). Regional pollution would bring more aged $\mathrm{BC}$ due to faster aging processes during atmospheric transport. The enhanced effect caused by more aged $\mathrm{BC}$ from atmospheric transport would further suppress the development of the boundary layer (e.g., Barbaro et al., 2013; Ding et al., 2016; Jacobson, 1998; Zdunkowski et al., 1976; Wendisch et al., 2008; Z. Wang et al., 2018), and together with the special haze chemistry (Cheng et al., 2016) strongly strengthens regional pollution.

\section{Concluding remarks}

The effect of BC-containing particles on air quality and climate is not only dominated by $\mathrm{BC}$ mass concentration, but is also controlled by their mixing state. To better understand the mixing state of atmospheric BC in China, we developed a new approach to simulate the $\mathrm{BC}$ aging process during atmospheric transport based on the $\mathrm{BC}$ emission inventory and back-trajectory analysis. Our models track the $\mathrm{BC}$ mixing state (i.e., $D_{\mathrm{p}} / D_{\mathrm{c}}$ ratio) from an emitted source origin (e.g., 
a $0.25^{\circ} \times 0.25^{\circ}$ grid) to a receptor (i.e., Tsinghua site). The model calculation can quantify the mass-averaged $D_{\mathrm{p}} / D_{\mathrm{c}}$ ratio of overall $\mathrm{BC}$ particles over the receptor site from various origins, which agreed well with observed ones. The simulations can provide information on the BC mixing state with fine temporal and spatial resolutions.

Based on the simulations of $\mathrm{BC}$ mixing state during atmospheric transport, we find a strong dependence of $\mathrm{BC}$ mixing state on emissions during atmospheric transport. BC particles with higher aging degrees at our site were mainly from more intensive emission origins (e.g., southern Hebei) due to higher aging rates. On the other hand, when $\mathrm{BC}$ particles emitted from clean origins passed through polluted regions, they were also characterized by a greater $D_{\mathrm{p}} / D_{\mathrm{c}}$ ratio by speeding up the aging process in polluted air. Our simulations demonstrated the importance of regional transport in BC light absorption in Beijing under polluted conditions. This provides a new perspective on the phenomenon of pollution building up in Beijing, further demonstrating that this is driven by regional transport and transformation rather than local sources and processes.

Data availability. The data used in this study can be provided upon request to Qiang Zhang (qiangzhang@tsinghua.edu.cn).

Supplement. The supplement related to this article is available online at: https://doi.org/10.5194/acp-19-9663-2019-supplement.

Author contributions. YZha and QZ designed the research and developed the model. YZha, HL and NW performed the field measurements. ML, YB, GG, CH, XL, DT, XZ, BZ and YZhe provided the emission data. YZha analyzed the data. YZha, QZ, YB, YC and HS interpreted the data. YZha and QZ wrote the manuscript with input from all the co-authors.

Competing interests. The authors declare that they have no conflict of interest.

Financial support. This research has been supported by the National Natural Science Foundation of China (grant nos. 41571130032, 41571130035, 41625020 and 91744310).

Review statement. This paper was edited by Aijun Ding and reviewed by Weijun $\mathrm{Li}$ and one anonymous referee.

\section{References}

Barbaro, E., Vilà-Guerau de Arellano, J., Krol, M. C., and Holtslag, A. A. M.: Impacts of Aerosol Shortwave Radiation Ab- sorption on the Dynamics of an Idealized Convective Atmospheric Boundary Layer, Bound.-Lay. Meteorol., 148, 31-49, https://doi.org/10.1007/s10546-013-9800-7, 2013.

Bond, T. C., Doherty, S. J., Fahey, D. W., Forster, P. M., Berntsen, T., DeAngelo, B. J., Flanner, M. G., Ghan, S., Kärcher, B., Koch, D., Kinne, S., Kondo, Y., Quinn, P. K., Sarofim, M. C., Schultz, M. G., Schulz, M., Venkataraman, C., Zhang, H., Zhang, S., Bellouin, N., Guttikunda, S. K., Hopke, P. K., Jacobson, M. Z., Kaiser, J. W., Klimont, Z., Lohmann, U., Schwarz, J. P., Shindell, D., Storelvmo, T., Warren, S. G., and Zender, C. S.: Bounding the role of black carbon in the climate system: A scientific assessment, J. Geophys. Res.-Atmos., 118, 5380-5552, https://doi.org/10.1002/jgrd.50171, 2013.

Cappa, C. D., Onasch, T. B., Massoli, P., Worsnop, D. R., Bates, T. S., Cross, E. S., Davidovits, P., Hakala, J., Hayden, K. L., Jobson, B. T., Kolesar, K. R., Lack, D. A., Lerner, B. M., Li, S.-M., Mellon, D., Nuaaman, I., Olfert, J. S., Petäjä, T., Quinn, P. K., Song, C., Subramanian, R., Williams, E. J., and Zaveri, R. A.: Radiative Absorption Enhancements Due to the Mixing State of Atmospheric Black Carbon, Science, 337, 1078-1081, https://doi.org/10.1126/science.1223447, 2012.

Cheng, Y. F., Eichler, H., Wiedensohler, A., Heintzenberg, J., Zhang, Y. H., Hu, M., Herrmann, H., Zeng, L. M., Liu, S., Gnauk, T., Brüggemann, E., and He, L. Y.: Mixing state of elemental carbon and non-light-absorbing aerosol components derived from in situ particle optical properties at Xinken in Pearl River Delta of China, J. Geophys. Res.-Atmos., 111, D20204, https://doi.org/10.1029/2005JD006929 2006.

Cheng, Y. F., Wiedensohler, A., Eichler, H., Su, H., Gnauk, T., Brüggemann, E., Herrmann, H., Heintzenberg, J., Slanina, J., Tuch, T., Hu, M., and Zhang, Y. H.: Aerosol optical properties and related chemical apportionment at Xinken in Pearl River Delta of China, Atmos. Environ., 42, 6351-6372, https://doi.org/10.1016/j.atmosenv.2008.02.034, 2008.

Cheng, Y. F., Berghof, M., Garland, R. M., Wiedensohler, A., Wehner, B., Müller, T., Su, H., Zhang, Y. H., Achtert, P., Nowak, A., Pöschl, U., Zhu, T., Hu, M., and Zeng, L. M.: Influence of soot mixing state on aerosol light absorption and single scattering albedo during air mass aging at a polluted regional site in northeastern China, J. Geophys. Res.-Atmos., 114, D00G10, https://doi.org/10.1029/2008JD010883, 2009.

Cheng, Y. F., Su, H., Rose, D., Gunthe, S. S., Berghof, M., Wehner, B., Achtert, P., Nowak, A., Takegawa, N., Kondo, Y., Shiraiwa, M., Gong, Y. G., Shao, M., Hu, M., Zhu, T., Zhang, Y. H., Carmichael, G. R., Wiedensohler, A., Andreae, M. O., and Pöschl, U.: Size-resolved measurement of the mixing state of soot in the megacity Beijing, China: diurnal cycle, aging and parameterization, Atmos. Chem. Phys., 12, 4477-4491, https://doi.org/10.5194/acp-12-4477-2012, 2012.

Cheng, Y., Su, H., Koop, T., Mikhailov, E., and Pöschl, U.: Size dependence of phase transitions in aerosol nanoparticles, Nat. Commun., 6, 5923, https://doi.org/10.1038/ncomms6923, 2015.

Cheng, Y., Zheng, G., Wei, C., Mu, Q., Zheng, B., Wang, Z., Gao, M., Zhang, Q., He, K., and Carmichael, G.: Reactive nitrogen chemistry in aerosol water as a source of sulfate during haze events in China, Sci. Adv., 2, e1601530, https://doi.org/10.1126/sciadv.1601530, 2016.

Chung, C. E., Ramanathan, V., and Decremer, D.: Observationally constrained estimates of carbonaceous aerosol radia- 
tive forcing, P. Natl. Acad. Sci. USA, 109, 11624-11629, https://doi.org/10.1073/pnas.1203707109, 2012.

Cooke, W. F. and Wilson, J. J. N.: A global black carbon aerosol model, J. Geophys. Res.-Atmos., 101, 19395-19409, https://doi.org/10.1029/96JD00671, 1996.

Dahlkötter, F., Gysel, M., Sauer, D., Minikin, A., Baumann, R., Seifert, P., Ansmann, A., Fromm, M., Voigt, C., and Weinzierl, B.: The Pagami Creek smoke plume after long-range transport to the upper troposphere over Europe - aerosol properties and black carbon mixing state, Atmos. Chem. Phys., 14, 6111-6137, https://doi.org/10.5194/acp-14-6111-2014, 2014.

Ding, A. J., Huang, X., Nie, W., Sun, J. N., Kerminen, V. M., Petäjä, T., Su, H., Cheng, Y. F., Yang, X. Q., Wang, M. H., Chi, X. G., Wang, J. P., Virkkula, A., Guo, W. D., Yuan, J., Wang, S. Y., Zhang, R. J., Wu, Y. F., Song, Y., Zhu, T., Zilitinkevich, S., Kulmala, M., and Fu, C. B.: Enhanced haze pollution by black carbon in megacities in China, Geophys. Res. Lett., 43, 2873-2879, https://doi.org/10.1002/2016GL067745, 2016.

Ditas, J., Ma, N., Zhang, Y., Assmann, D., Neumaier, M., Riede, H., Karu, E., Williams, J., Scharffe, D., Wang, Q., Saturno, J., Schwarz, J. P., Katich, J. M., McMeeking, G. R., Zahn, A., Hermann, M., Brenninkmeijer, C. A. M., Andreae, M. O., Pöschl, U., Su, H., and Cheng, Y.: Strong impact of wildfires on the abundance and aging of black carbon in the lowermost stratosphere, P. Natl. Acad. Sci. USA, 115, E11595-E11603, https://doi.org/10.1073/pnas.1806868115, 2018.

Gao, R. S., Schwarz, J. P., Kelly, K. K., Fahey, D. W., Watts, L. A., Thompson, T. L., Spackman, J. R., Slowik, J. G., Cross, E. S., Han, J. H., Davidovits, P., Onasch, T. B., and Worsnop, D. R.: A Novel Method for Estimating LightScattering Properties of Soot Aerosols Using a Modified SingleParticle Soot Photometer, Aerosol Sci. Technol., 41, 125-135, https://doi.org/10.1080/02786820601118398, 2007.

Gustafsson, Ö. and Ramanathan, V.: Convergence on climate warming by black carbon aerosols, P. Natl. Acad. Sci. USA, 113, 4243-4245, https://doi.org/10.1073/pnas.1603570113, 2016.

Healy, R. M., Wang, J. M., Jeong, C.-H., Lee, A. K. Y., Willis, M. D., Jaroudi, E., Zimmerman, N., Hilker, N., Murphy, M., Eckhardt, S., Stohl, A., Abbatt, J. P. D., Wenger, J. C., and Evans, G. J.: Light-absorbing properties of ambient black carbon and brown carbon from fossil fuel and biomass burning sources, J. Geophys. Res.-Atmos., 120, 6619-6633, https://doi.org/10.1002/2015jd023382, 2015

Jacobson, M. Z.: Studying the effects of aerosols on vertical photolysis rate coefficient and temperature profiles over an urban airshed, J. Geophys. Res.-Atmos., 103, 10593-10604, https://doi.org/10.1029/98JD00287, 1998.

Jacobson, M. Z.: Strong radiative heating due to the mixing state of black carbon in atmospheric aerosols, Nature, 409, 695-697, https://doi.org/10.1038/35055518, 2001.

Koch, K.: Transport and direct radiative forcing of carbonaceous and sulphate aerosols in the GISS GCM, J. Geophys. Res.-Atmos., 106, 20311-20332, https://doi.org/10.1029/2001JD900038, 2001.

Kondo, Y., Matsui, H., Moteki, N., Sahu, L., Takegawa, N., Kajino, M., Zhao, Y., Cubison, M. J., Jimenez, J. L., Vay, S., Diskin, G. S., Anderson, B., Wisthaler, A., Mikoviny, T., Fuelberg, H. E., Blake, D. R., Huey, G., Weinheimer, A. J., Knapp, D. J., and Brune, W. H.: Emissions of black carbon, organic, and inorganic aerosols from biomass burning in North America and Asia in 2008, J. Geophys. Res.-Atmos., 116, D08204, https://doi.org/10.1029/2010jd015152, 2011.

Lack, D. A. and Cappa, C. D.: Impact of brown and clear carbon on light absorption enhancement, single scatter albedo and absorption wavelength dependence of black carbon, Atmos. Chem. Phys., 10, 4207-4220, https://doi.org/10.5194/acp10-4207-2010, 2010.

Laborde, M., Crippa, M., Tritscher, T., Jurányi, Z., Decarlo, P. F., Temime-Roussel, B., Marchand, N., Eckhardt, S., Stohl, A., Baltensperger, U., Prévôt, A. S. H., Weingartner, E., and Gysel, M.: Black carbon physical properties and mixing state in the European megacity Paris, Atmos. Chem. Phys., 13, 5831-5856, https://doi.org/10.5194/acp-13-5831-2013, 2013.

Li, M., Zhang, Q., Kurokawa, J.-I., Woo, J.-H., He, K., Lu, Z., Ohara, T., Song, Y., Streets, D. G., Carmichael, G. R., Cheng, Y., Hong, C., Huo, H., Jiang, X., Kang, S., Liu, F., Su, H., and Zheng, B.: MIX: a mosaic Asian anthropogenic emission inventory under the international collaboration framework of the MICS-Asia and HTAP, Atmos. Chem. Phys., 17, 935-963, https://doi.org/10.5194/acp-17-935-2017, 2017.

Li, W., Sun, J., Xu, L., Shi, Z., Riemer, N., Sun, Y., Fu, P., Zhang, J., Lin, Y., Wang, X., Shao, L., Chen, J., Zhang, X., Wang, Z., and Wang, W.: A conceptual framework for mixing structures in individual aerosol particles, J. Geophys. Res.-Atmos., 121, 1378413798, https://doi.org/10.1002/2016jd025252, 2016.

Liu, D., Allan, J. D., Young, D. E., Coe, H., Beddows, D., Fleming, Z. L., Flynn, M. J., Gallagher, M. W., Harrison, R. M., Lee, J., Prevot, A. S. H., Taylor, J. W., Yin, J., Williams, P. I., and Zotter, P.: Size distribution, mixing state and source apportionment of black carbon aerosol in London during wintertime, Atmos. Chem. Phys., 14, 10061-10084, https://doi.org/10.5194/acp-1410061-2014, 2014.

Liu, D., Joshi, R., Wang, J., Yu, C., Allan, J. D., Coe, H., Flynn, M. J., Xie, C., Lee, J., Squires, F., Kotthaus, S., Grimmond, S., Ge, X., Sun, Y., and Fu, P.: Contrasting physical properties of black carbon in urban Beijing between winter and summer, Atmos. Chem. Phys., 19, 6749-6769, https://doi.org/10.5194/acp19-6749-2019, 2019.

Liu, D., Whitehead, J., Alfarra, M. R., Reyes-Villegas, E., Spracklen, D. V., Reddington, C. L., Kong, S., Williams, P. I., Ting, Y.-C., Haslett, S., Taylor, J. W., Flynn, M. J., Morgan, W. T., McFiggans, G., Coe, H., and Allan, J. D.: Black-carbon absorption enhancement in the atmosphere determined by particle mixing state, Nature Geosci., 10, 184-188, https://doi.org/10.1038/ngeo2901, 2017.

Liu, H., Pan, X., Liu, D., Liu, X., Chen, X., Tian, Y., Sun, Y., Fu, P., and Wang, Z.: Mixing characteristics of refractory black carbon aerosols determined by a tandem CPMA-SP2 system at an urban site in Beijing, Atmos. Chem. Phys. Discuss., https://doi.org/10.5194/acp-2019-244, in review, 2019.

Liu, S., Aiken, A. C., Gorkowski, K., Dubey, M. K., Cappa, C. D., Williams, L. R., Herndon, S. C., Massoli, P., Fortner, E. C., Chhabra, P. S., Brooks, W. A., Onasch, T. B., Jayne, J. T., Worsnop, D. R., China, S., Sharma, N., Mazzoleni, C., Xu, L., Ng, N. L., Liu, D., Allan, J. D., Lee, J. D., Fleming, Z. L., Mohr, C., Zotter, P., Szidat, S., and Prévôt, A. S. H.: Enhanced light absorption by mixed source black and 
brown carbon particles in UK winter, Nat Commun., 6, 8435, https://doi.org/10.1038/ncomms9435, 2015.

Lohmann, U., Feichter, J., Penner, J., and Leaitch, R.: Indirect effect of sulfate and carbonaceous aerosols: a mechanistic treatment, J. Geophys. Res.-Atmos., 105, 12193-12206, https://doi.org/10.1029/1999JD901199, 2000.

Lu, Z., Streets, D. G., Zhang, Q., and Wang, S.: A novel backtrajectory analysis of the origin of black carbon transported to the Himalayas and Tibetan Plateau during 1996-2010, Geophys. Res. Lett., 39, L01809, https://doi.org/10.1029/2011GL049903, 2012

Matsui, H., Koike, M., Kondo, Y., Moteki, N., Fast, J. D., and Zaveri, R. A.: Development and validation of a black carbon mixing state resolved three-dimensional model: Aging processes and radiative impact, J. Geophys. Res.-Atmos., 118, 2304-2326, https://doi.org/10.1029/2012JD018446, 2013.

McMeeking, G. R., Morgan, W. T., Flynn, M., Highwood, E. J., Turnbull, K., Haywood, J., and Coe, H.: Black carbon aerosol mixing state, organic aerosols and aerosol optical properties over the United Kingdom, Atmos. Chem. Phys., 11, 9037-9052, https://doi.org/10.5194/acp-11-9037-2011, 2011.

Moffet, R. C. and Prather, K. A.: In-situ measurements of the mixing state and optical properties of soot with implications for radiative forcing estimates, P. Natl. Acad. Sci. USA, 106, 1187211877, https://doi.org/10.1073/pnas.0900040106, 2009.

Moteki, N. and Kondo, Y.: Dependence of Laser-Induced Incandescence on Physical Properties of Black Carbon Aerosols: Measurements and Theoretical Interpretation, Aerosol Sci. Technol., 44, 663-675, https://doi.org/10.1080/02786826.2010.484450, 2010.

Moteki, N., Kondo, Y., Miyazaki, Y., Takegawa, N., Komazaki, Y., Kurata, G., Shirai, T., Blake, D. R., Miyakawa, T., and Koike, M.: Evolution of mixing state of black carbon particles: Aircraft measurements over the western Pacific in March 2004, Geophys. Res. Lett., 34, L11803, https://doi.org/10.1029/2006GL028943, 2007.

Morgan, W. T., Allan, J. D., Bauguitte, S., Darbyshire, E., Flynn, M. J., Lee, J., Liu, D., Johnson, B., Haywood, J., Longo, K. M., Artaxo, P. E., and Coe, H.: Transformation and aging of biomass burning carbonaceous aerosol over tropical South America from aircraft in-situ measurements during SAMBBA, Atmos. Chem. Phys. Discuss., https://doi.org/10.5194/acp-2019-157, in review, 2019

Mu, Q., Shiraiwa, M., Octaviani, M., Ma, N., Ding, A., Su, H., Lammel, G., Pöschl, U., and Cheng, Y.: Temperature effect on phase state and reactivity controls atmospheric multiphase chemistry and transport of PAHs, Sci. Adv., 4, eaap7314, https://doi.org/10.1126/sciadv.aap7314, 2018.

Myhre, G., Berglen, T. F., Johnsrud, M., Hoyle, C. R., Berntsen, T. K., Christopher, S. A., Fahey, D. W., Isaksen, I. S. A., Jones, T. A., Kahn, R. A., Loeb, N., Quinn, P., Remer, L., Schwarz, J. P., and Yttri, K. E.: Modelled radiative forcing of the direct aerosol effect with multi-observation evaluation, Atmos. Chem. Phys., 9, 1365-1392, https://doi.org/10.5194/acp-9-1365-2009, 2009.

Nordmann, S., Cheng, Y. F., Carmichael, G. R., Yu, M., Denier van der Gon, H. A. C., Zhang, Q., Saide, P. E., Pöschl, U., Su, H., Birmili, W., and Wiedensohler, A.: Atmospheric black carbon and warming effects influenced by the source and absorption en- hancement in central Europe, Atmos. Chem. Phys., 14, 1268312699, https://doi.org/10.5194/acp-14-12683-2014, 2014.

Oshima, N., Koike, M., Zhang, Y., Kondo, Y., Moteki, N., Takegawa, N., and Miyazaki, Y.: Aging of black carbon in outflow from anthropogenic sources using a mixing state resolved model: Model development and evaluation, J. Geophys. Res.Atmos., 114, D06210, https://doi.org/10.1029/2008JD010680, 2009.

Pan, X., Kanaya, Y., Taketani, F., Miyakawa, T., Inomata, S., Komazaki, Y., Tanimoto, H., Wang, Z., Uno, I., and Wang, Z.: Emission characteristics of refractory black carbon aerosols from fresh biomass burning: a perspective from laboratory experiments, Atmos. Chem. Phys., 17, 13001-13016, https://doi.org/10.5194/acp-17-13001-2017, 2017.

Peng, J., Hu, M., Guo, S., Du, Z., Zheng, J., Shang, D., Levy Zamora, M., Zeng, L., Shao, M., Wu, Y.-S., Zheng, J., Wang, Y., Glen, C. R., Collins, D. R., Molina, M. J., and Zhang, R.: Markedly enhanced absorption and direct radiative forcing of black carbon under polluted urban environments, P. Natl. Acad. Sci. USA, 113, 4266-4271, https://doi.org/10.1073/pnas.1602310113, 2016.

Ramanathan, V. and Carmichael, G.: Global and regional climate changes due to black carbon, Nature Geosci., 1, 221-227, https://doi.org/10.1038/ngeo156, 2008.

Ramnarine, E., Kodros, J. K., Hodshire, A. L., Lonsdale, C. R., Alvarado, M. J., and Pierce, J. R.: Effects of nearsource coagulation of biomass burning aerosols on global predictions of aerosol size distributions and implications for aerosol radiative effects, Atmos. Chem. Phys., 19, 6561-6577, https://doi.org/10.5194/acp-19-6561-2019, 2019.

Riemer, N., Vogel, H., and Vogel, B.: Soot aging time scales in polluted regions during day and night, Atmos. Chem. Phys., 4, 1885-1893, https://doi.org/10.5194/acp-4-1885-2004, 2004.

Riemer, N., West, M., Zaveri, R. A., and Easter, R. C.: Simulating the evolution of soot mixing state with a particleresolved aerosol model, J. Geophys. Res.-Atmos., 114, D09202, https://doi.org/10.1029/2008jd011073, 2009.

Schulz, M., Textor, C., Kinne, S., Balkanski, Y., Bauer, S., Berntsen, T., Berglen, T., Boucher, O., Dentener, F., Guibert, S., Isaksen, I. S. A., Iversen, T., Koch, D., Kirkevåg, A., Liu, X., Montanaro, V., Myhre, G., Penner, J. E., Pitari, G., Reddy, S., Seland, Ø., Stier, P., and Takemura, T.: Radiative forcing by aerosols as derived from the AeroCom present-day and pre-industrial simulations, Atmos. Chem. Phys., 6, 5225-5246, https://doi.org/10.5194/acp6-5225-2006, 2006.

Sedlacek, A. J., Lewis, E. R., Kleinman, L., Xu, J., and Zhang, Q.: Determination of and evidence for non-core-shell structure of particles containing black carbon using the Single-Particle Soot Photometer (SP2), Geophys. Res. Lett., 39, L06802, https://doi.org/10.1029/2012GL050905, 2012.

Shi, S., Cheng, T., Gu, X., Guo, H., Wu, Y., and Wang, Y.: Biomass burning aerosol characteristics for different vegetation types in different aging periods, Environ. Int., 126, 504-511, https://doi.org/10.1016/j.envint.2019.02.073, 2019.

Shiraiwa, M., Kondo, Y., Moteki, N., Takegawa, N., Miyazaki, Y., and Blake, D. R.: Evolution of mixing state of black carbon in polluted air from Tokyo, Geophys. Res. Lett., 34, L16803, https://doi.org/10.1029/2007GL029819, 2007. 
Sun, Y., Jiang, Q., Wang, Z., Fu, P., Li, J., Yang, T., and Yin, Y.: Investigation of the sources and evolution processes of severe haze pollution in Beijing in January 2013, J. Geophys. Res.-Atmos., 119, 4380-4398, https://doi.org/10.1002/2014JD021641, 2014.

Schwarz, J. P., Gao, R. S., Spackman, J. R., Watts, L. A., Thomson, D. S., Fahey, D. W., Ryerson, T. B., Peischl, J., Holloway, J. S., and Trainer, M.: Measurement of the mixing state, mass, and optical size of individual black carbon particles in urban and biomass burning emissions, Geophys. Res. Lett., 35, L13810, https://doi.org/10.1029/2008GL033968, 2008.

Taylor, J. W., Allan, J. D., Liu, D., Flynn, M., Weber, R., Zhang, X., Lefer, B. L., Grossberg, N., Flynn, J., and Coe, H.: Assessment of the sensitivity of core / shell parameters derived using the singleparticle soot photometer to density and refractive index, Atmos. Meas. Tech., 8, 1701-1718, https://doi.org/10.5194/amt-8-1701$2015,2015$.

Wang, L. T., Wei, Z., Yang, J., Zhang, Y., Zhang, F. F., Su, J., Meng, C. C., and Zhang, Q.: The 2013 severe haze over southern Hebei, China: model evaluation, source apportionment, and policy implications, Atmos. Chem. Phys., 14, 3151-3173, https://doi.org/10.5194/acp-14-3151-2014, 2014.

Wang, X., Heald, C. L., Ridley, D. A., Schwarz, J. P., Spackman, J. R., Perring, A. E., Coe, H., Liu, D., and Clarke, A. D.: Exploiting simultaneous observational constraints on mass and absorption to estimate the global direct radiative forcing of black carbon and brown carbon, Atmos. Chem. Phys., 14, 10989-11010, https://doi.org/10.5194/acp-14-10989-2014, 2014.

Wang, Y., Liu, F., He, C., Bi, L., Cheng, T., Wang, Z., Zhang, H., Zhang, X., Shi, Z., and Li, W.: Fractal Dimensions and Mixing Structures of Soot Particles during Atmospheric Processing, Environ. Sci. Technol. Lett., 4, 487-493, https://doi.org/10.1021/acs.estlett.7b00418, 2017.

Wang, Y., Ma, P.-L., Peng, J., Zhang, R., Jiang, J. H., Easter, R. C., and Yung, Y. L.: Constraining Aging Processes of Black Carbon in the Community Atmosphere Model Using Environmental Chamber Measurements, J. Adv. Model. Earth Sy., 10, 2514 2526, https://doi.org/10.1029/2018ms001387, 2018.

Wang, Z., Huang, X., and Ding, A.: Dome effect of black carbon and its key influencing factors: a one-dimensional modelling study, Atmos. Chem. Phys., 18, 2821-2834, https://doi.org/10.5194/acp-18-2821-2018, 2018.

Wendisch, M., Hellmuth, O., Ansmann, A., Heintzenberg, J., Engelmann, R., Althausen, D., Eichler, H., Müller, D., Hu, M., Zhang, Y., and Mao, J.: Radiative and dynamic effects of absorbing aerosol particles over the Pearl River Delta, China, Atmos. Environ., 42, 6405-6416, https://doi.org/10.1016/j.atmosenv.2008.02.033, 2008.

Willis, M. D., Healy, R. M., Riemer, N., West, M., Wang, J. M., Jeong, C.-H., Wenger, J. C., Evans, G. J., Abbatt, J. P. D., and Lee, A. K. Y.: Quantification of black carbon mixing state from traffic: implications for aerosol optical properties, Atmos. Chem. Phys., 16, 4693-4706, https://doi.org/10.5194/acp16-4693-2016, 2016.
Yang, Y. R., Liu, X. G., Qu, Y., An, J. L., Jiang, R., Zhang, Y. H., Sun, Y. L., Wu, Z. J., Zhang, F., Xu, W. Q., and Ma, Q. X.: Characteristics and formation mechanism of continuous hazes in China: a case study during the autumn of 2014 in the North China Plain, Atmos. Chem. Phys., 15, 8165-8178, https://doi.org/10.5194/acp-15-8165-2015, 2015.

Zdunkowski, W. G., Welch, R. M., and Paegle, J.: OneDimensional Numerical Simulation of the Effects of Air Pollution on the Planetary Boundary Layer, J. Atmos. Sci., 33, 2399-2414, https://doi.org/10.1175/15200469(1976)033<2399:ODNSOT>2.0.CO;2, 1976.

Zhang, Y., Zhang, Q., Cheng, Y., Su, H., Kecorius, S., Wang, Z., Wu, Z., Hu, M., Zhu, T., Wiedensohler, A., and He, K.: Measuring the morphology and density of internally mixed black carbon with SP2 and VTDMA: new insight into the absorption enhancement of black carbon in the atmosphere, Atmos. Meas. Tech., 9, 1833-1843, https://doi.org/10.5194/amt-9-1833-2016, 2016.

Zhang, Y., Li, X., Li, M., Zheng, Y., Geng, G., Hong, C., Li, H., Tong, D., Zhang, X., Cheng, Y., Su, H., He, K., and Zhang, Q.: Reduction in black carbon light absorption due to multipollutant emission control during APEC China 2014, Atmos. Chem. Phys., 18, 10275-10287, https://doi.org/10.5194/acp-1810275-2018, 2018a.

Zhang, Y., Su, H., Ma, N., Li, G., Kecorius, S., Wang, Z., Hu, M., Zhu, T., He, K., Wiedensohler, A., Zhang, Q., and Cheng, Y.: Sizing of Ambient Particles From a SingleParticle Soot Photometer Measurement to Retrieve Mixing State of Black Carbon at a Regional Site of the North China Plain, J. Geophys. Res.-Atmos., 123, 12778-12795, https://doi.org/10.1029/2018JD028810, 2018b.

Zhang, Y., Zhang, Q., Cheng, Y., Su, H., Li, H., Li, M., Zhang, X., Ding, A., and He, K.: Amplification of light absorption of black carbon associated with air pollution, Atmos. Chem. Phys., 18, 9879-9896, https://doi.org/10.5194/acp-18-9879-2018, 2018c.

Zheng, G. J., Duan, F. K., Su, H., Ma, Y. L., Cheng, Y., Zheng, B., Zhang, Q., Huang, T., Kimoto, T., Chang, D., Pöschl, U., Cheng, Y. F., and He, K. B.: Exploring the severe winter haze in Beijing: the impact of synoptic weather, regional transport and heterogeneous reactions, Atmos. Chem. Phys., 15, 2969-2983, https://doi.org/10.5194/acp-15-2969-2015, 2015.

Zheng, G., Duan, F., Ma, Y., Zhang, Q., Huang, T., Kimoto, T., Cheng, Y., Su, H., and He, K.: Episode-Based Evolution Pattern Analysis of Haze Pollution: Method Development and Results from Beijing, China, Environ. Sci. Technol., 50, 4632-4641, https://doi.org/10.1021/acs.est.5b05593, 2016. 